\title{
Quantification of anthropogenic impact on groundwater-dependent terrestrial ecosystem using geochemical and isotope tools combined with 3-D flow and transport modelling
}

\author{
A. J. Zurek ${ }^{1}$, S. Witczak ${ }^{1}$, M. Dulinski ${ }^{2}$, P. Wachniew ${ }^{2}$, K. Rozanski ${ }^{2}$, J. Kania ${ }^{1}$, A. Postawa ${ }^{1}$, J. Karczewski ${ }^{1}$, and \\ W. J. Moscicki ${ }^{1}$ \\ ${ }^{1}$ AGH University of Science and Technology, Faculty of Geology, Geophysics and Environmental Protection, Krakow, Poland \\ ${ }^{2}$ AGH University of Science and Technology, Faculty of Physics and Applied Computer Science, Krakow, Poland
}

Correspondence to: A. J. Zurek (zurek@agh.edu.pl)

Received: 11 June 2014 - Published in Hydrol. Earth Syst. Sci. Discuss.: 15 August 2014

Revised: 19 December 2014 - Accepted: 29 January 2015 - Published: 24 February 2015

\begin{abstract}
Groundwater-dependent ecosystems (GDEs) have important functions in all climatic zones as they contribute to biological and landscape diversity and provide important economic and social services. Steadily growing anthropogenic pressure on groundwater resources creates a conflict situation between nature and man which are competing for clean and safe sources of water. Such conflicts are particularly noticeable in GDEs located in densely populated regions. A dedicated study was launched in 2010 with the main aim to better understand the functioning of a groundwaterdependent terrestrial ecosystem (GDTE) located in southern Poland. The GDTE consists of a valuable forest stand (Niepolomice Forest) and associated wetland (Wielkie Błoto fen). It relies mostly on groundwater from the shallow Quaternary aquifer and possibly from the deeper Neogene (Bogucice Sands) aquifer. In July 2009 a cluster of new pumping wells abstracting water from the Neogene aquifer was set up $1 \mathrm{~km}$ to the northern border of the fen. A conceptual model of the Wielkie Błoto fen area for the natural, pre-exploitation state and for the envisaged future status resulting from intense abstraction of groundwater through the new well field was developed. The main aim of the reported study was to probe the validity of the conceptual model and to quantify the expected anthropogenic impact on the studied GDTE. A wide range of research tools was used. The results obtained through combined geologic, geophysical, geochemical, hydrometric and isotope investigations provide strong evidence for the existence of upward seepage of groundwater from the deeper Neogene aquifer to the shallow Quaternary aquifer
\end{abstract}

supporting the studied GDTE. Simulations of the groundwater flow field in the study area with the aid of a 3-D flow and transport model developed for Bogucice Sands (Neogene) aquifer and calibrated using environmental tracer data and observations of hydraulic head in three different locations on the study area, allowed us to quantify the transient response of the aquifer to operation of the newly established Wola Batorska well field. The model runs reveal the presence of upward groundwater seepage to the shallow Quaternary aquifer of the order of $440 \mathrm{~m}^{3} \mathrm{~d}^{-1}$. By the end of the simulation period (2029), with continuous operation of the Wola Batorska well field at maximum permissible capacity (ca. $10000 \mathrm{~m}^{3}$ $\mathrm{d}^{-1}$ ), the direction of groundwater seepage will change sign (total change of the order of $900 \mathrm{~m}^{3} \mathrm{~d}^{-1}$ ). The water table drawdown in the study area will reach ca. $30 \mathrm{~cm}$. This may have significant adverse effects on functioning of the studied GDTE.

\section{Introduction}

There is a growing awareness among policy makers, legislators, water resources managers and researchers of the important environmental and socio-economic functions of groundwater-dependent ecosystems (GDEs) as reflected, for example, in the environmental legislation of the European Union (Kløve et al., 2011b; EC, 2000, 2006). Human needs and GDEs appear as two, sometimes conflicting, groundwater uses (Wachniew et al., 2014) which need to be man- 


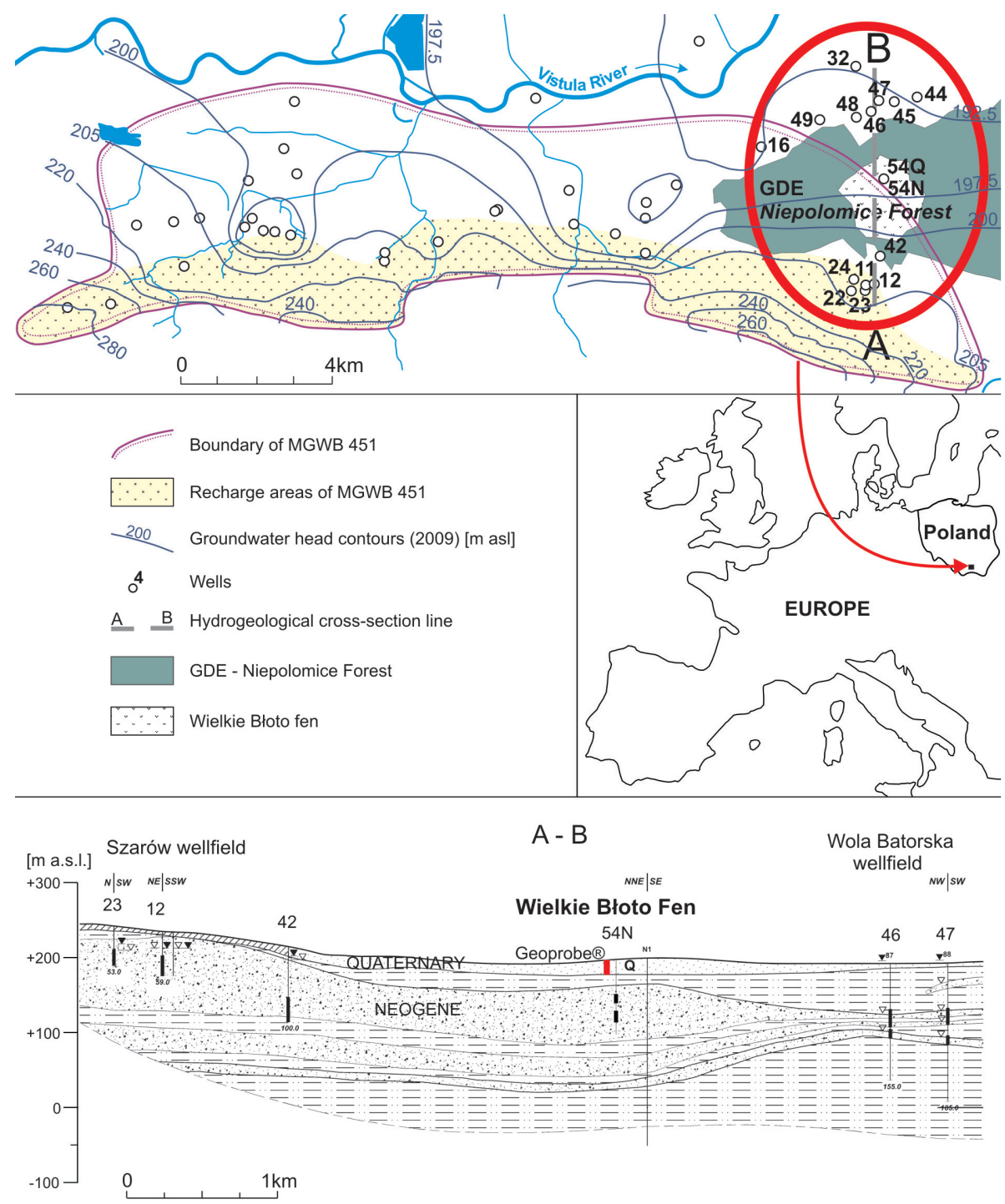

Figure 1. Hydrogeological map and cross-section of the Bogucice Sands (Neogene) aquifer (major groundwater basin - MGWB 451). The study area is marked by a red oval. Open circles mark the position of pumping wells. Cross-section according to Górka et al. (2010).

aged in an integrated, multidisciplinary manner (Kløve et al., 2011b). Groundwater exploitation, climatic and land-use changes, pollution as well as other pressures on groundwater quantity and quality affect functions of the GDEs, yet the relationships between groundwater systems and the performance of dependent ecosystems are not fully understood (Kløve et al., 2011a, b, 2014). The great diversity of GDEs stems primarily from space and time variations of groundwater supply to those ecosystems. Various classifications of GDEs (Hatton and Evans, 1998; Sinclair Knight Merz, 2001; EC, 2003, 2011; Boulton, 2005; Pettit et al., 2007; Dresel et al., 2010; Kløve et al., 2011a; Bertrand et al., 2012) reflect this diversity. The basic division includes the terrestrial (GDTE; e.g. wet forests, riparian zones, wetlands) and aquatic (GDAE; e.g. springs, lakes, rivers with hyporheic zones, lagoons) GDEs.

Sustainable management of GDEs requires that their vulnerability to anthropogenic impacts is assessed (Wachniew et al., 2014). A conceptualization of GDE vulnerability must include understanding of two factors: (i) the degree of ecosystem reliance on groundwater (Hatton and Evans, 1998), and (ii) groundwater availability to the ecosystem (Sinclair Knight Merz, 2001). Consequently, a substantial component of conceptual models, on which vulnerability assessments are based (EC, 2010), is related to the identification of the origin and pathways and quantification of groundwater fluxes to GDEs.

The presented study was aimed at comprehensive investigation of groundwater dependence of a terrestrial ecosystem 
(GDTE) consisting of valuable forest stand and associated wetland, located in the south of Poland (Fig. 1). The central hypothesis of the presented work was that the studied GDTE relies not only on the shallow, unconfined Quaternary aquifer but indirectly also on groundwater originating from deeper confined aquifer, underlying the Quaternary cover and separated from it by an aquitard of variable thickness. Consequently, the presented study was addressing flow paths and water ages of the deeper aquifer and its connectivity with the shallow Quaternary aquifer. An important additional objective was the quantification of the potential risk to the studied GDTE associated with the operation of a nearby cluster of water-supply wells exploiting the deeper aquifer. The deeper aquifer is an important source of drinking water for the local population, intensely exploited for several decades now.

A suite of tools were applied to address the problems outlined above. Two monitoring wells were drilled in the centre of the studied GDTE to obtain direct information on the vertical extent and geologic structure of the Quaternary cover and the deeper aquifer. The drillings were supplemented by geophysical prospecting. DC resistivity sounding was used to obtain additional information about the spatial extent and thickness of the confining layer separating the Quaternary cover and the underlying deeper Neogene aquifer. Groundpenetrating radar surveys supplied information about the thickness of peat layers in the area of GDTE. Hydrometric measurements, carried out over a 2-year period on the Dluga Woda stream draining the area of GDTE and supported by chemical and isotope analyses of stream water, were used to quantify the expected contribution of groundwater seepage from the deeper aquifer to the water balance of the Dluga Woda catchment. The seepage was further characterized by dedicated Geoprobe ${ }^{\circledR}$ sampling of the Quaternary cover enabling vertical stratification of environmental tracers and water chemistry within the Quaternary cover to be assessed. The hydrochemical evolution and age of water in the Neogene (Bogucice Sands) aquifer was characterized using chemical and isotope data (water chemistry, stable isotopes of water $\left({ }^{2} \mathrm{H}\right.$ and $\left.{ }^{18} \mathrm{O}\right)$, tritium $\left({ }^{3} \mathrm{H}\right)$, isotopes of carbon $\left.\left({ }^{14} \mathrm{C},{ }^{13} \mathrm{C}\right)\right)$ accompanied by geochemical modelling (PHREEQC and NETPATH). Finally, the 3-D flow and transport model available for the Bogucice Sands aquifer was used to quantify the expected impact of enhanced exploitation of the aquifer on the status of the studied GDTE.

The presented study focusing on the interaction between the Bogucice Sands (Neogene) aquifer and the associated GDTE is a follow-up of the earlier work concerned mostly with the dynamics and geochemical evolution of groundwater in the deeper aquifer (Zuber et al., 2005; Witczak et al., 2008; Dulinski et al., 2013).

\section{The study area}

The study area is located in the south of Poland, in the vicinity of Krakow agglomeration (Fig. 1). The studied GDTE consists of valuable forest stand - the Niepolomice Forest, and associated wetland - the Wielkie Błoto fen. The Niepolomice Forest is a relatively large (ca. $110 \mathrm{~km}^{2}$ ) lowland forest complex. This relict of once vast forests occupying southern Poland is protected as a Natura 2000 Special Protection Area "Puszcza Niepołomicka" (PLB120002) which supports bird populations of European importance. The Niepolomice Forest contains also several nature reserves and the European bison breeding centre and has important recreational value as the largest forest complex in the vicinity of Krakow agglomeration.

The Wielkie Błoto fen located in the western part of Niepolomice Forest (Figs. 1 and 2) comprises a separate Natura 2000 area (Torfowisko Wielkie Błoto, PLH120080), a significant habitat of endangered butterfly species associated with wet meadows. It contains different types of peat deposits with variable thickness (Fig. 2). Due to drainage works carried out mostly after the Second World War, the uppermost peat layers were drained and converted to arable land (Lipka, 1989; Łajczak, 1997; Lipka et al., 2006). In recent decades the agriculture usage of Wielkie Błoto was greatly reduced and the studied GDTE is returning nowadays to its natural state.

The climate of the study area has an intermediate character between oceanic and continental, with mean annual temperature of $8.2^{\circ} \mathrm{C}$. Mean annual precipitation rate amounts to $725 \mathrm{~mm}$ whereas the mean actual evapotranspiration in the Niepolomice Forest area reaches $480 \mathrm{~mm}$. The annual mean runoff fluctuates around $245 \mathrm{~mm}$. The regional runoff is related to the drainage system of Vistula River and its tributaries (see Fig. 1). The Wielkie Błoto fen area and the adjacent parts of Niepolomice Forest are drained by the Dluga Woda stream with $8.2 \mathrm{~km}^{2}$ of gauged catchment area (Fig. 2).

Depth to the water table in the study area is generally small, with wetlands and marshes occurring in several parts of the Niepolomice Forest. The dependence of Niepolomice Forest stands on groundwater is enhanced by low available water capacity and low capillary rise of the soils supporting the forest (Łajczak, 1997; Chełmicki et al., 2003). Depth to water table was used as a basis for defining an index quantifying dependency of Niepolomice Forest on groundwater. This dependency relies on rooting depth and the depth to local water table. It also influences the typology of forest and type of plant cover associated with GDTE (Schaffers and Sýkora, 2000; Pettit et al., 2007; GENESIS, 2012; Hose et al., 2014). The rooting depth must be smaller than the depth to the water table. Otherwise water-clogging occurs and roots cannot respire due to excess of water in the soil profile. Three classes of GDTE susceptibility to changes of water table depth were proposed (Fig. 2): (i) class A: very strongly dependent (depth of water table ranging from 0.0 

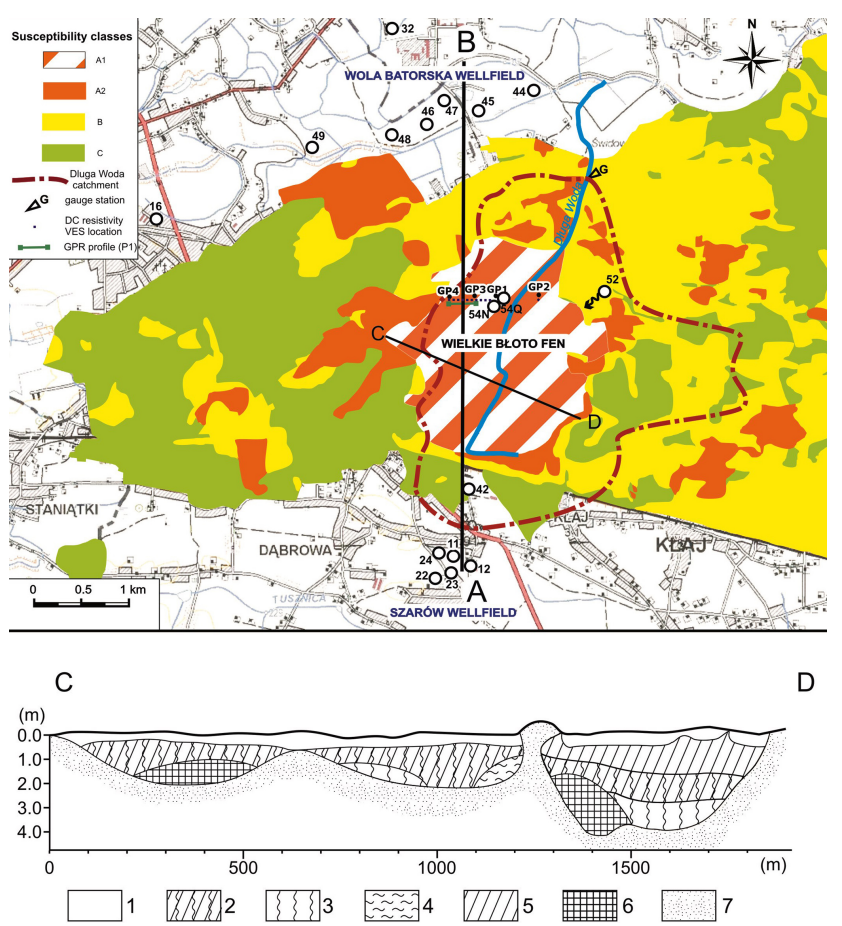

Figure 2. Upper panel: map of the study area showing the western part of Niepolomice Forest and Wielkie Błoto fen. GDTE susceptibility classes based on the depth to water table: A - very strongly dependent ( 0.0 to $0.5 \mathrm{~m})$; A 1 - wetland ecosystem; A2 - forest ecosystem; B - strongly dependent $(0.5$ to $2.0 \mathrm{~m})$ forest ecosystem; C weakly dependent $(>2.0 \mathrm{~m})$ forest ecosystem. Lower panel: crosssection through Wielkie Błoto fen according Lipka (1989). 1 - mineralized peat soil; 2 - tall sedge-reed peat; 3 - reed peat; 4 - Sphagnum peat; 5 - tall sedge peat; 6 - gyttja; 7 - sand.

to $0.5 \mathrm{~m}$ ), (ii) class B: strongly dependent ( 0.5 to $2.0 \mathrm{~m})$, and (iii) class $\mathrm{C}$ : weakly dependent $(>2.0 \mathrm{~m})$. Forest stands growing on areas where depth to water table exceeds $2 \mathrm{~m}$ utilize mostly soil moisture and are weakly dependent on groundwater level fluctuations. Forest stands on areas with shallower water table are more susceptible to changes in groundwater level, regardless of their direction (Forest Management Manual, 2012).

Groundwater is stored in the study area in the upper, phreatic aquifer associated with Quaternary sediments and in the confined, deeper aquifer composed of Neogene marine sediments (Bogucice Sands). The unsaturated zone consists mainly of sands and loess of variable thickness, from a fraction of a metre in wetland areas to approximately $30 \mathrm{~m}$ in the recharge area of the deeper aquifer layers.

The Bogucice Sands (Neogene) aquifer covers an area of ca. $200 \mathrm{~km}^{2}$ and belongs to the category of major groundwater basins (MGWB) in Poland (Kleczkowski et al., 1990). It is located on the border of the Carpathian Foredeep Basin and belongs to the Upper Badenian (Middle Miocene). The aquifer (MGWB no. 451) is composed mainly of unconsolidated sands, locally sandstones with carbonate cement. The variable percentage of carbonate cement, up to $30 \%$, affects the hydraulic conductivity of water-bearing horizons. The aquifer is underlined by impermeable clays and claystones of the Chodenice Beds (Porebski and Oszczypko, 1999). To the north, the aquifer is progressively covered by mudstones and claystones with thin sandstone interbeds. Palaeoflow directional indicators suggest proximity to deltaic shoreline. The mean thickness of the aquifer is approximately $100 \mathrm{~m}$, with two water-bearing horizons (see Fig. 1). The hydrogeology of the aquifer can be considered in three areas: (i) the recharge area related to the outcrops of Bogucice Sands in the south, (ii) the central confined area generally with artesian water, and (iii) the northern discharge area in the Vistula River valley. Groundwater movement takes place from the outcrops in the south, in the direction of the Vistula River valley (Fig. 1) where the aquifer is drained by upward seepage through semi-permeable aquitard. The recharge of groundwater, related to outcropping lithology, is of the order of 8 to $28 \%$ of annual precipitation.

The principal economic role of Bogucice Sands aquifer is to provide potable water for public and private users. Estimated safe yield of the aquifer is approximately $40000 \mathrm{~m}^{3} \mathrm{~d}^{-1}$, with typical well capacities of 4 to $200 \mathrm{~m}^{3} \mathrm{~h}^{-1}$ (Kleczkowski et al., 1990; Witczak et al., 2008; Górka et al., 2010). Hospitals and food processing plants also exploit some wells. Yield of the aquifer is insufficient to meet all present and emerging needs and, as a consequence, licensing conflicts arise between water supply companies and industry about the amount of water available for safe exploitation.

In the pre-exploitation era, artesian water existed most probably on the entire confined area of the aquifer. Intensive exploitation decreased the hydraulic head in some areas causing downward seepage. In the area of Wielkie Błoto fen the aquifer is exploited by Szarów well field located in the south (wells Nos. 11, 12, 22-24, 42 in Figs. 1 and 2). In July 2009 a cluster of six new water-supply wells (Wola Batorska well field - wells Nos. 44-49 in Figs. 1 and 2) exploiting deeper aquifer layers was set up close to the northern border of Niepolomice Forest. There is a growing concern that intense exploitation of this new well field may lead to lowering of hydraulic head in the western part of the Niepolomice Forest area.

The available geological information (Porebski and Oszczypko, 1999; Górka et al., 2010), supplemented by the results of previous work on the dynamics and geochemical evolution of groundwater in the Bogucice Sand aquifer (Zuber et al., 2005; Witczak et al., 2008), provided the basis for construction of a conceptual model illustrating the interaction between shallow Quaternary aquifer and the deeper Neogene aquifer in the area of studied GDTE and suggesting the possible impact of intense exploitation of groundwater by the Wola Batorska well field (Fig. 3). Figure 3a presents the presumed natural state of this interaction. The Wielkie Błoto fen represents in this model a local discharge area for both the shallow and the deeper aquifer. Artesian conditions in 

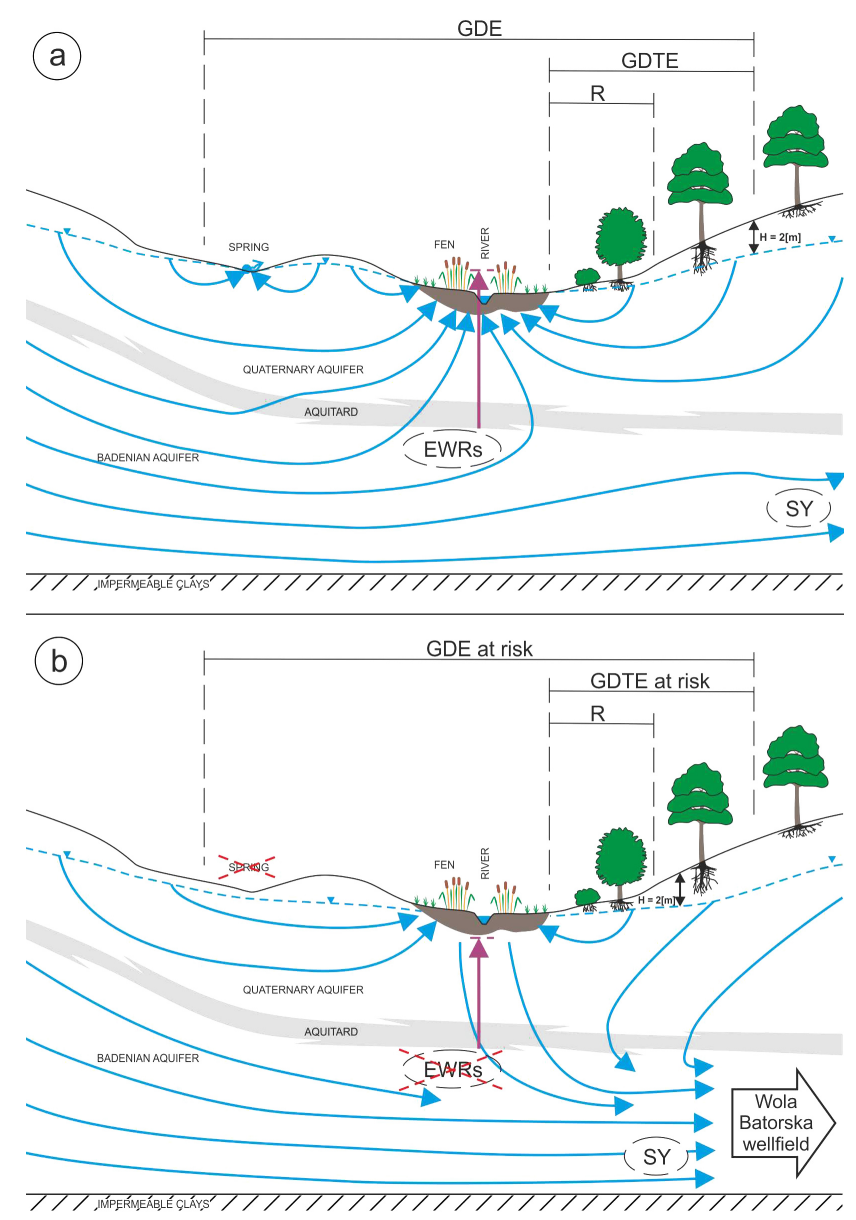

Figure 3. Conceptual model of the Wielkie Błoto fen. (a) Natural state; (b) envisaged future status as a result of intense exploitation of the Wola Batorska well field. GDE - groundwater-dependent ecosystem; GDTE - groundwater-dependent terrestrial ecosystem; $\mathrm{R}$ - riparian forest; EWRs - environmental water requirements; SY - safe yield of the aquifer exploited by the Wola Batorska well field.

the deeper aquifer combined with the relatively thin aquitard layer separating both aquifers may lead to upward seepage of deeper groundwater, contributing to the water balance of the studied GDTE. The envisaged future status of the shallow/deep aquifer interaction as a result of intense exploitation of the Wola Batorska well field is shown in Fig. $3 b$. It is expected that intensive pumping of the deeper aquifer by the well field localized close to the northern border of Niepołomice Forest (wells Nos. 44-49 in Fig. 2), exceeding its safe yield, may modify the groundwater flow field in the area of Wielkie Błoto fen in such a way that the upward leakage will be stopped or significantly reduced, thus leading to a lowering of the water table and endangering the environmental water requirements of the studied GDTE.

\section{Materials and methods}

A suite of different methods was applied to address two major questions posed by the conceptual model presented in Fig. 3, i.e. the existence of upward seepage of groundwater from the deeper Neogene aquifer to the shallow Quaternary aquifer and its role in the water balance of Wielkie Błoto fen, and quantification of the expected impact of intense exploitation of the deeper aquifer by the Wola Batorska well field on groundwater flow in the study area, in particular on the postulated upward seepage of groundwater. Four major areas of investigation were pursued: (i) verifying the available information on the vertical extent and geologic structure of the shallow Quaternary aquifer and the deeper Neogene aquifer in the area of the studied GDTE through direct (drillings) and indirect (geophysical prospecting) observations, (ii) assessing, through hydrometric observations, the water balance of the Dluga Woda stream draining the area of Wielkie Błoto fen, (iii) extensive sampling of surface water and groundwater in the study area for chemical and isotope analyses, aimed at quantifying the dynamics of water flow and tracing the postulated upward seepage of groundwater, and (iv) modelling of expected changes in groundwater flow in the study area, in response to intense pumping by the Wola Batorska well field.

The Geoprobe ${ }^{\circledR}$ direct push device (Model 420M) was used to perform vertical profiling of the Quaternary cover in the area of Wielkie Błoto, combined with sampling of water at different depths. Water samples were collected at GP1, GP3 and GP4 sites (Fig. 2). Site GP2 did not yield enough water for sampling. In addition, soil cores were collected at GP1, GP2 and GP3 sites (Fig. 4). The Geoprobe ${ }^{\circledR}$ profiling verified the position of the aquitard separating the shallow and deep aquifer in the study area. PVC screened pipes with a 2.5 inch outside diameter were installed in GP1, GP2 and GP3 for subsequent observations of water table.

In July 2014, two monitoring wells were drilled in the centre of the Wielkie Błoto fen (see Fig. 2). The well no. 54N reached the depth of $97.5 \mathrm{~m}$ penetrating the Quaternary cover and reaching the deeper Neogene aquifer (see Figs. 1 and 4). The second well (no. 54Q) was drilled to the depth of $8 \mathrm{~m}$. Both wells were screened (see Table 1) and water samples were collected for chemical and isotope analyses. Also, measurements of hydraulic heads in both Quaternary and Neogene aquifers were made.

Geoprobe $^{\circledR}$ profiling and direct drillings were supplemented by geophysical prospecting. Surface DC resistivity sounding surveys were used as a reconnaissance tool to assess the depth and thickness of clay and claystone layers separating the shallow aquifer from the deeper aquifer in the area of Wielkie Błoto fen. The vertical electrical sounding (VES) surveys with the Schlumberger array (Koefoed, 1979) were applied at 11 locations, linked to the locations of Geoprobe ${ }^{\circledR}$ profiling (Fig. 2). Quantitative interpretation of the apparent resistivity as a function of electrode spac- 


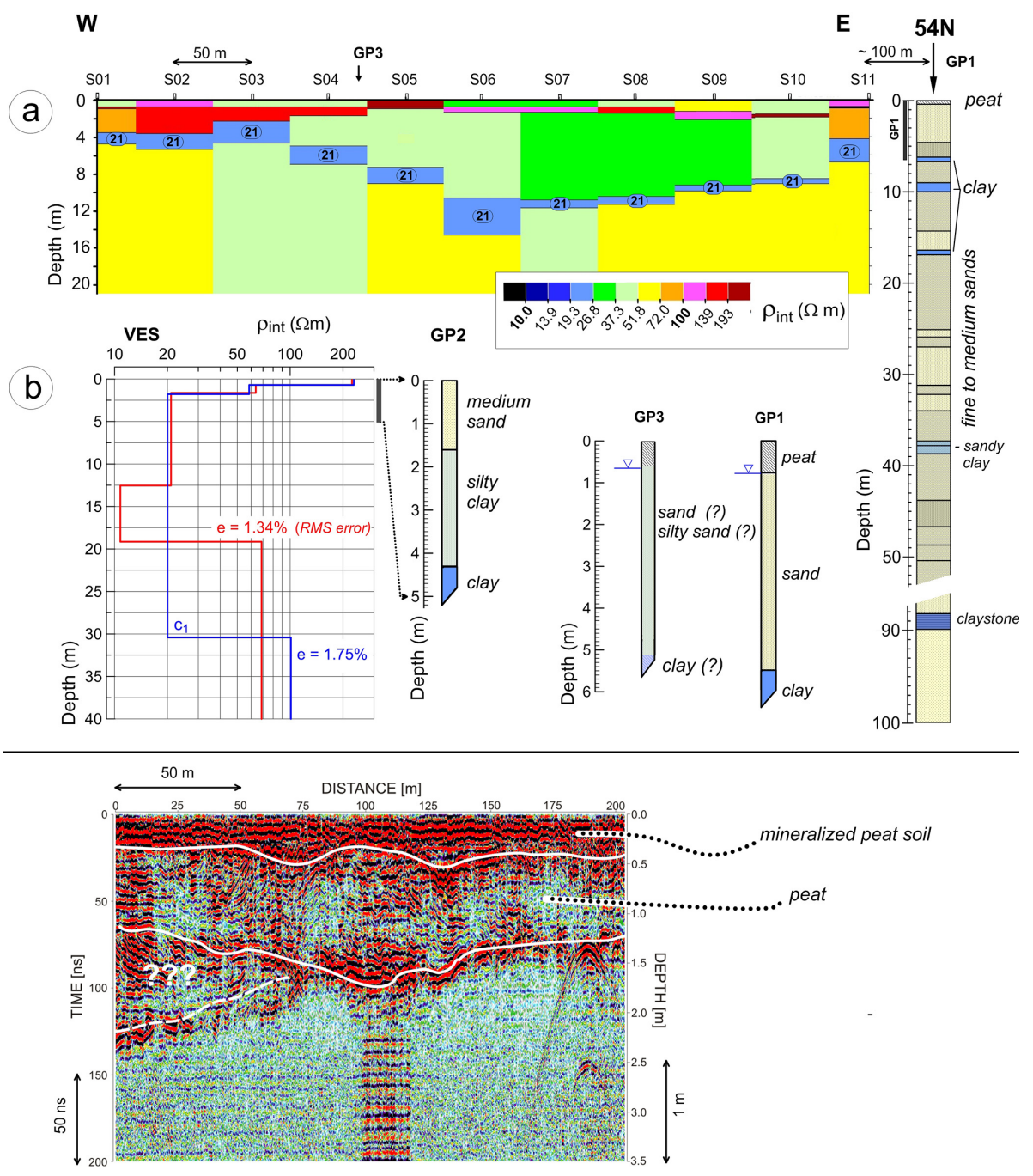

Figure 4. Upper panel: the results of vertical electrical sounding (VES). (a) 1-D interpreted resistivity section (S01-S11). Clay layer marked in blue. (b) Two variants of interpreted resistivity vertical profile based on VES sounding in the vicinity of GP 2 site. C1 corresponds to fixed resistivity of clay equal to $21 \mathrm{Ohmm}$. Also shown are the geological logs of Geoprobe ${ }^{\circledR}$ soil cores at GP1, GP2 and GP3 and the borehole drilled in the centre of the Wielkie Błoto fen (54N). Lower panel: GPR echogram along the P1 profile shown in Fig. 2 (see text for details).

ing (VES curve) was performed with the aid of RESIS and IPI2WIN software (Mościcki, 2005; Bobachev, 2010). The ground-penetrating radar (GPR) method (Daniels, 2004) was applied to assess the thickness of peat layers in the area of Wielkie Błoto fen. This method has been successfully used in the past to delineate the location of peat layers in various environments (e.g. Warner et al., 1990; Slater and Reeve, 2002; Plado et al., 2011). A short electromagnetic pulse generated by a transmitting antenna of georadar propagates in the shallow subsurface and is reflected back from the geological strata which differ in relative dielectric permittivity $\left(\varepsilon_{\mathrm{r}}\right)$, defined as the ratio of the measured dielectric permittivity to the dielectric permittivity of vacuum. Peat layers are characterized by very high $\varepsilon_{\mathrm{r}}$ values (60-75) while sandy layers show $\varepsilon_{\mathrm{r}}$ values of the order of 10-15, depending on actual water content. The GPR surveys were performed with a ProEx System (MALA Geoscience), using offset configuration with co-polarized $250 \mathrm{MHz}$ centre frequency shielded antenna. Seven separate GPR profiles with total length of approximately $1400 \mathrm{~m}$ were obtained (see Fig. 2).

In order to detect the hydraulic response of the aquifer to the operation of the new pumping wells located in Wola Batorska, systematic observations of the hydraulic head in well no. 32, situated ca. $1 \mathrm{~km}$ north of the Wola Batorska well field, were performed (see Fig. 2). Initially, the depth of water table was measured manually using a water level meter. Starting from 4 July 2012, automatic recording of the position of the water table using a pressure transducer was performed. Well no. 32 maintained artesian conditions prior to establishing the cluster of the new water-supply wells.

The network for collecting water samples for chemical and isotope analyses is shown in Fig. 2. Field procedures 
for hydrochemical sampling were similar to those described by Salminen et al. (2005). Unfiltered water was collected in $500 \mathrm{~mL}$ polyethylene bottles for major ion analysis. Filtered water was acidified using $\mathrm{HNO}_{3}$ to $\mathrm{pH}<2$ and collected to new hardened polyethylene $100 \mathrm{~mL}$ bottles for major, minor and trace components. For $\mathrm{pH}$ and Eh field determinations, two laboratory-calibrated instruments were used. They were immerged in the pumped water until equilibrium was reached and a minimal difference between both instruments was recorded. Then, the mean value of both readings was taken as the accepted value. Alkalinity was measured in the field by titration method. Inductively coupled plasma mass spectrometry (ICP-MS) and other routine methods were used for determination of the chemical composition of the water samples collected during the study (exploratory boreholes, water-supply wells, Dluga Woda stream, Geoprobe ${ }^{\circledR}$ samples). Samples of water for isotope analysis were collected using established protocols. Isotope and chemical data were also obtained for the "Anna Spring" (no. 52 in Fig. 2). Groundwater appearance at this site is linked to a badly sealed borehole drilled in 1970s for seismic prospecting.

Samples for chemical and isotope analysis of the Dluga Woda stream were collected at gauge station G (Fig. 2) over the 2-year period from August 2011 to August 2013, at roughly monthly intervals (see Table 4 ). The purpose of this monitoring activity was the identification and quantification of the expected contribution of the upward seepage from the Bogucice Sands (Neogene) aquifer to the total discharge of the Dluga Woda stream draining the Wielkie Błoto area. Initially, both the stages and flow rates of the Dluga Woda were recorded. They provided the basis for constructing the rating curve of the stream. Subsequently, a pressure transducer was installed for continuous stream-level monitoring, starting from June 2012. A discharge hydrograph of the Dluga Woda stream was then generated for the entire observation period.

Tritium $\left({ }^{3} \mathrm{H}\right)$ and radiocarbon $\left({ }^{14} \mathrm{C}\right)$ concentrations in the analysed groundwater samples (water and total dissolved inorganic carbon pool, respectively) were measured at the AGH University of Science and Technology in Krakow by electrolytic enrichment followed by liquid scintillation spectrometry for tritium, and benzene synthesis followed by liquid scintillation spectrometry for ${ }^{14} \mathrm{C}$. Tritium concentrations are reported in tritium units (TU) (1 TU corresponds to the ratio ${ }^{3} \mathrm{H} /{ }^{1} \mathrm{H}$ equal $10^{-18}$ ). Radiocarbon content is reported in percent of modern carbon (pMC), following recommendations of Stuiver and Polach (1977) and Mook and van der Plicht (1999). The stable isotope composition of water $\left(\delta^{18} \mathrm{O}\right.$, $\left.\delta^{2} \mathrm{H}\right)$ and TDIC pool $\left(\delta^{13} \mathrm{C}\right)$ was determined in the same laboratory by dual-inlet isotope-ratio mass spectrometry and reported on V-SMOW and V-PDB scales (Coplen, 1996). Typical uncertainties of ${ }^{3} \mathrm{H},{ }^{14} \mathrm{C}, \delta^{18} \mathrm{O}, \delta^{2} \mathrm{H}$ and $\delta^{13} \mathrm{C}$ analyses were of the order of $0.5 \mathrm{TU}, 0.7 \mathrm{pMC}, 0.1 \%$, $1 \%$ and $0.1 \%$, respectively. Dissolved carbonates in the analysed groundwater samples were precipitated in the field from ca. $60 \mathrm{~L}$ of water following the established procedures (Florkowski et al., 1975; Clark and Fritz, 1997).

Chemical composition of groundwater samples collected in the recharge area was modelled using PHREEQC (Version 2.18) geochemical code (Parkhurst and Appelo, 1999). Piston-flow radiocarbon ages of groundwater in the confined part of the studied system were calculated for using NETHPATH code (Fontes et al., 1979; Plummer et al., 1994).

The existing 3-D numerical model of the Bogucice Sands aquifer was employed to investigate the impact of Wola Batorska well field on groundwater flow in the area of Wielkie Błoto fen. The MODFLOW-2000 code for simulation of flow (Harbaugh et al., 2000) and MT3DMS code (Zengh and Wang, 1999) for modelling mass transport, both incorporated in the Visual MODFLOW 2011.1 Pro (Schlumberger Water Services, 2011) were used. The finitedifference grid consisted of five layers with 27225 rectangular cells $(250 \times 250 \mathrm{~m}, 72$ rows and 129 columns $)$. The longitudinal dispersivity $\left(\alpha_{\mathrm{L}}\right)$ was assumed to be $50 \mathrm{~m}$. Although the selected size of computational cells did not satisfy the criterion $\Delta x<2 \alpha_{\mathrm{L}}$ required for avoiding the numerical dispersion (Kinzelbach, 1986), its influence was reduced by applying the total-variation-diminishing method (TVD - Zheng and Wang, 1999; Hill and Tiedeman, 2007). The MODFLOW River Package was used to simulate the exchange of water between the aquifer and the surface water with head-dependent seepage interaction. The agreement between calculated and observed heads was satisfactory. Hydraulic heads were maintained in subsequent calibrations of the transport model with the aid of tracer data (Zuber et al., 2005; Witczak et al., 2008). In this process the hydraulic conductivity and the aquifer thickness were modified in individual grid cells, without changing adopted transmissivity values. The changes of aquifer thickness were constrained by available geological information. Three water-bearing layers were distinguished in the model: one layer in the shallow Quaternary aquifer and two layers in the deeper Neogene aquifer. Transient flow simulations were performed by the model, with quarterly pumping rates of Wola Batorska well field during the period July 2009-September 2013 and with maximum permitted capacity of $10080 \mathrm{~m}^{3} \mathrm{~d}^{-1}$, starting from the end of 2014 and continuing to the end of 2029.

\section{Results and discussion}

\subsection{Delineation of vertical structure of the Quaternary cover and the Neogene aquifer in the area of Wielkie Błoto fen}

The geological structure of the Neogene (Bogucice Sands) aquifer in the area of Wielkie Błoto fen, emerging from the results of Geoprobe ${ }^{\circledR}$ profiling and exploratory drillings, is shown in Fig. 4. At site GP1 and GP3 unconsolidated sands reach the thickness of 5.5 and $5 \mathrm{~m}$, respectively. Below 
Table 1. Environmental tracer data for groundwater samples collected in the study area (n.m.: not measured).

\begin{tabular}{|c|c|c|c|c|c|c|c|}
\hline Site/Well no. & $\begin{array}{l}\text { Depth }^{\mathrm{a}} \\
\text { (m) }\end{array}$ & $\begin{array}{l}\delta^{2} \mathrm{H} \\
(\% o)\end{array}$ & $\begin{array}{l}\delta^{18} \mathrm{O} \\
(\% o)\end{array}$ & $\begin{array}{l}\text { d-excess } \\
(\% o)\end{array}$ & $\begin{array}{l}\text { Tritium } \\
\text { (TU) }\end{array}$ & $\begin{array}{l}\delta^{13} \mathrm{C}_{\mathrm{TDIC}} \\
(\% \circ)\end{array}$ & $\begin{array}{l}{ }^{14} \mathrm{C}_{\mathrm{TDIC}} \\
(\mathrm{pMC})\end{array}$ \\
\hline \multicolumn{8}{|c|}{ Szarów } \\
\hline Well no. 11 & $49.5-60.1$ & -70.3 & -9.75 & 7.7 & 9.0 & -14.1 & 64.6 \\
\hline Well no. 12 & $44.5-63.6$ & -70.1 & -9.93 & 9.3 & 1.1 & -12.8 & 63.6 \\
\hline Well no. 22 & $48.0-60.0$ & -69.4 & -9.81 & 9.1 & 16.1 & n.m. & n.m. \\
\hline Well no. 42 & $70.0-95.0$ & -69.2 & -9.68 & 8.2 & $<0.3$ & -12.2 & 48.5 \\
\hline \multicolumn{8}{|c|}{ Wola Batorska ${ }^{b}$} \\
\hline Well no. 44 & $98.0-144.0$ & -75.7 & -10.19 & 5.8 & $<0.3$ & -10.2 & 3.2 \\
\hline Well no. 45 & $75.0-149.0$ & -78.3 & -10.67 & 7.1 & $<0.3$ & n.m. & n.m. \\
\hline Well no. 16 & $107.5-143.1$ & -69.7 & -10.03 & 10.5 & $<0.3$ & -13.3 & 32.1 \\
\hline Well no. 32 & $90.9-102.0$ & -76.8 & -10.93 & 10.6 & $<0.3$ & -10.6 & $<0.7$ \\
\hline \multicolumn{8}{|c|}{ Wielkie Błoto area } \\
\hline GP1-A & 1.6 & -70.8 & -10.07 & 9.8 & 8.1 & n.m. & n.m. \\
\hline GP1-B & 2.8 & -68.2 & -9.65 & 9.0 & 5.4 & n.m. & n.m. \\
\hline GP1-C & 4.6 & -71.0 & -10.10 & 9.8 & 0.9 & n.m. & n.m. \\
\hline GP3-A & 1.6 & -61.9 & -8.83 & 8.7 & 10.1 & n.m & n.m. \\
\hline GP3-B & 3.1 & -69.3 & -9.86 & 9.6 & 1.4 & n.m. & n.m. \\
\hline GP4-A & 1.6 & -64.4 & -9.09 & 8.3 & 6.5 & n.m. & n.m. \\
\hline GP4-B & 4.0 & -69.6 & -9.67 & 7.8 & 2.1 & -14.3 & $57.2^{\mathrm{c}}$ \\
\hline
\end{tabular}

a Screen position in the production wells; maximum depth for Geoprobe ${ }^{\circledR}$ sampling; ${ }^{b}$ isotope data reported for wells Nos. 44,46 and 49 are arithmetic averages of the results obtained in three consecutive sampling campaigns carried out in June 2010, July 2012 and October 2013; ${ }^{\mathrm{c}}$ analysed using AMS technique; ${ }^{\mathrm{d}}$ badly sealed borehole drilled in the 1970s for seismic prospecting (see Figs. 1 and 2).

this depth, mudstones and claystones start to appear, making deeper penetration of Geoprobe ${ }^{\circledR}$ not possible. At both locations a thin layer of peat at ca. $50-70 \mathrm{~cm}$ was identified. The water table was located at the same depth. At GP2 site peat was absent and the mudstone layer began at only $1.8 \mathrm{~m}$ depth.

Interpretation of the apparent resistivity profiles from VES surveys was performed for 11 sections located near GP1, GP3 and GP4 sites. The interpreted values of resistivity $\left(\rho_{\text {int }}\right)$ obtained on the basis of VES curves are presented in Fig. 4 in the form of depth profiles of $\rho_{\text {int }}$ along the 11 studied sections (S01-S11, Fig. 2). The selection of VES curves was aided by additional measurements performed in the vicinity of GP2 site which allowed us to select a fixed resistivity value $(21 \Omega \mathrm{m})$ representing clay layers in the profile. It is worth noting that the clay layer (blue) seen in the upper panel of Fig. 4 is very thin in some places (less than ca. $1 \mathrm{~m}$ ), with possible discontinuities facilitating hydraulic contact of deeper aquifer layers with the shallow Quaternary aquifer.
The interpreted resistivity of the strata lying above the clay layer roughly corresponds to sand with high water content. The uppermost layer is characterized by distinctly higher resistivity which can be linked to the presence of peat (see discussion below).

The monitoring wells drilled in July 2014 confirmed the results obtained from VES profiling. The simplified geological profile of well no. 54N shown in Fig. 4 revealed that the thickness of the aquitard separating the shallow Quaternary aquifer and the deeper Neogene aquifer is rather small. Three mudstone layers were identified in the profile. The thickness of the largest layer does not exceed one metre and occurs at the depth of $9 \mathrm{~m}$.

The total length of the GPR profiles obtained in the area of Wielkie Błoto exceeded $1400 \mathrm{~m}$. Here only one echogram representing the distance of approximately $200 \mathrm{~m}$ (profile P1 in Fig. 2) is discussed. Based on the data available for the soil core collected at GP1 site, electromagnetic wave velocity in 
Table 2. Physico-chemical parameters of groundwater samples collected in the study area (n.m.: not measured).

\begin{tabular}{|c|c|c|c|c|c|c|c|c|c|c|}
\hline Site/Well no. & $\begin{array}{l}\text { Temp. } \\
\left({ }^{\circ} \mathrm{C}\right)\end{array}$ & $\mathrm{pH}$ & $\begin{array}{l}\text { SEC } \\
\left(\mu \mathrm{S} \mathrm{cm}^{-1}\right)\end{array}$ & $\begin{array}{l}\mathrm{Ca} \\
\left(\mathrm{mg} \mathrm{L}^{-1}\right)\end{array}$ & $\begin{array}{l}\mathrm{Mg} \\
\left(\mathrm{mg} \mathrm{L}^{-1}\right)\end{array}$ & $\begin{array}{l}\mathrm{Na} \\
\left(\mathrm{mg} \mathrm{L}^{-1}\right)\end{array}$ & $\begin{array}{l}\mathrm{K} \\
\left(\mathrm{mg} \mathrm{L}^{-1}\right)\end{array}$ & $\begin{array}{l}\mathrm{HCO}_{3} \\
\left(\mathrm{mg} \mathrm{L}^{-1}\right)\end{array}$ & $\begin{array}{l}\mathrm{Cl} \\
\left(\mathrm{mg} \mathrm{L}^{-1}\right)\end{array}$ & $\begin{array}{l}\mathrm{SO}_{4} \\
\left(\mathrm{mg} \mathrm{L}^{-1}\right)\end{array}$ \\
\hline \multicolumn{11}{|c|}{ Szarów } \\
\hline Well no. 11 & 11.5 & 7.1 & 733 & 116 & 16.5 & 10.1 & 1.27 & 384 & 23.3 & 41.1 \\
\hline Well no. 12 & 11.5 & 7.1 & 646 & 107 & 15.8 & 6.91 & 1.19 & 394 & 7.38 & 21.8 \\
\hline Well no. 22 & 11.0 & 7.0 & 607 & 105 & 17.1 & 7.54 & 1.42 & 410 & 8.82 & 19.2 \\
\hline Well no. 23 & 11.5 & 7.5 & 906 & 138 & 17.4 & 20.5 & 1.51 & 340 & 45.1 & 87.3 \\
\hline Well no. 24 & 11.0 & 7.1 & 542 & 96.8 & 15.6 & 6.53 & 1.59 & 306 & 20.4 & 57.3 \\
\hline Well no. 42 & 11.6 & 7.1 & n.m. & 117 & 18.4 & 25.7 & 1.49 & 350 & 15.5 & 77.2 \\
\hline \multicolumn{11}{|c|}{ Wola Batorska } \\
\hline Well no. 44 & 12.7 & 8.7 & 745 & 6.28 & 1.71 & 170 & 2.67 & 395 & 28.2 & $<3.0$ \\
\hline Well no. 45 & 12.4 & 8.1 & 780 & 19.2 & 5.13 & 160 & 4.69 & 448 & 51.0 & $<3.0$ \\
\hline Well no. 46 & 13.2 & 8.3 & 768 & 16.5 & 3.48 & 153 & 3.27 & 388 & 49.7 & $<3.0$ \\
\hline Well no. 47 & 14.1 & 8.1 & 824 & 23.6 & 4.98 & 174 & 3.70 & 436 & 60.4 & $<3.0$ \\
\hline Well no. 48 & 16.8 & 8.1 & 855 & 16.9 & 3.68 & 178 & 4.43 & 468 & 28.5 & 8.10 \\
\hline Well no. 49 & 12.5 & 8.7 & 1152 & 10.3 & 2.67 & 250 & 4.12 & 429 & 79.8 & 21.0 \\
\hline Well no. 16 & 13.0 & 7.4 & 1313 & 80.4 & 16.6 & 160 & 7.28 & 413 & 200.0 & 19.2 \\
\hline Well no. 32 & 12.0 & 8.3 & 717 & 5.62 & 1.68 & 139 & 5.84 & 324 & 65.3 & 0.59 \\
\hline \multicolumn{11}{|c|}{ Wielkie Błoto area } \\
\hline GP1-A & 11.2 & 6.0 & 352 & 50.0 & 3.72 & 11.7 & 2.21 & 76.3 & 13.9 & 81.1 \\
\hline GP1-B & 11.8 & 7.1 & 899 & 78.4 & 14.7 & 65.8 & 5.44 & 276 & 57.5 & 112.0 \\
\hline GP1-C & 12.3 & 7.6 & 960 & 46.9 & 13.8 & 123 & 7.92 & 278 & 119.0 & 68.0 \\
\hline GP3-A & 12.3 & 7.2 & 549 & 97.3 & 9.36 & 8.90 & 2.20 & 221 & 25.9 & 66.9 \\
\hline GP3-B & 15.3 & 8.2 & 1150 & 48.4 & 17.9 & 163 & 7.88 & 398 & 121.0 & 44.2 \\
\hline GP4-A & 11.8 & 6.6 & 568 & 99.8 & 10.6 & 9.46 & 1.85 & 298 & 21.1 & 39.2 \\
\hline GP4-B & 11.6 & 8.8 & 1054 & 136 & 32.7 & 51.9 & 8.49 & 473 & 43.3 & 129.0 \\
\hline "Anna Spring" (no. 52) & 9.0 & 7.7 & 390 & 40.2 & 8.72 & 31.9 & 6.17 & 288 & 5.74 & $<3.0$ \\
\hline Well no. 54Q & 12.6 & 6.5 & 706 & 81.6 & 16.0 & 48.7 & 8.09 & 207 & 51.2 & 141 \\
\hline Well no. 54N & 12.5 & 7.4 & 1576 & 15.7 & 16.3 & 276 & 9.56 & 424 & 244 & 26.0 \\
\hline
\end{tabular}

peat was set at $v=3.6 \mathrm{~cm} \mathrm{nsec}^{-1}$. This value was then used to construct the depth scale of the echogram presented in the lower panel of Fig. 4. A peat layer located between ca. 0.4 and $1.2 \mathrm{~m}$ can be distinguished. The boundary located at approximately $0.4 \mathrm{~m}$ depth can be linked to degraded mineralized peat soil, also visible in the vertical cross-section shown in the lower panel of Fig. 2. Due to high attenuation of the signal, the border between sands and clays seen in the apparent resistivity profile presented in the upper panel of Fig. 4 could not be identified.

\subsection{Geochemical evolution and age of groundwater in the Neogene aquifer}

Table 1 summarizes environmental tracer data obtained for water samples collected in the production wells of the Bogucice Sands (Neogene) aquifer and during Geoprobe ${ }^{\circledR}$ survey of the Quaternary cover in the area of Wielkie Błoto fen. The corresponding physico-chemical parameters are summarized in Table 2.

Deuterium and oxygen-18 isotope composition of the water in the production wells located in the study area and tapping the Bogucice Sands (Neogene) aquifer is shown in Fig. 5a in $\delta^{2} \mathrm{H}-\delta^{18} \mathrm{O}$ space, against the background of global and local meteoric water lines and the mean isotopic composition of modern recharge. As seen in Fig. 5a, all wells located in the eastern part of the recharge area (Szarów well field, wells Nos. 11, 12, 22, 23, 24) cluster around the mean isotopic composition of modern recharge. All of them contain tritium, testifying to the recent origin of groundwater in this area. Radiocarbon content was measured in two wells (Nos. 11, 12) and shows values around $64 \mathrm{pMC}$, in the range of radiocarbon concentrations measured in other wells located in the recharge area of the Bogucice Sands aquifer (see Fig. 1). Reduced concentrations of radiocarbon in recharge waters containing tritium result from geochemical evolution of TDIC reservoir in these waters (see e.g. Dulinski et al., 2013). Stable isotope composition of water in well no. 42 , located ca. $1 \mathrm{~km}$ north of the Szarów well field also belongs to this cluster of points in Fig. 5a. This water is devoid of tritium and reveals reduced radiocarbon concentration (ca. $48 \mathrm{pMC}$ ) pointing to its pre-bomb (Holocene) age. The same applies to newly drilled monitoring well tapping the Neogene aquifer (no. $54 \mathrm{~N})$. Its radiocarbon content $(30 \mathrm{pMC})$ reflects a gradual aging of the water along the flow lines starting in the recharge area (Szarów well field). Well no. 54Q tapping the Quaternary aquifer shows significant concentration of tritium and reduced radiocarbon content, in agreement with expectations. The stable isotope composition of waters collected during Geoprobe ${ }^{\circledR}$ survey from different levels of the Quaternary cover scatter along the local meteoric water line reflects seasonal variations of $\delta^{2} \mathrm{H}$ and $\delta^{18} \mathrm{O}$ in local precipitation (see Sect. 4.4). 
The stable isotope composition of water in wells belonging to the newly established well field in Wola Batorska reveals a systematic shift towards more negative $\delta^{2} \mathrm{H}$ and $\delta^{18} \mathrm{O}$ values, clearly indicating recharge in a colder climate (Rozanski, 1985; Zuber et al., 2004). This groundwater does not contain tritium and shows low radiocarbon content, of the order of few pMC, also suggesting a glacial age of this water (see discussion below). In well no. 32, located ca. $1 \mathrm{~km}$ north of the Wola Batorska well field, the radiocarbon content of TDIC reservoir drops below the detection limit $(<0.7 \mathrm{pMC})$ suggesting a significant increase in age of the groundwater, while maintaining the characteristic stable isotope signature of this water indicating recharge in a cold climate (Fig. 5). In contrast, the stable isotope composition of water in well no. 16, located ca. $2 \mathrm{~km}$ southwest of Wola Batorska well field (see Fig. 2) shows higher radiocarbon content ( $32.1 \mathrm{pMC}$ ), lack of tritium and stable isotope composition of water suggesting its Holocene origin. The same applies to "Anna Spring" (no. 52) located in the forest, east of Wielkie Błoto fen.

Waters in the recharge zone of the investigated part of the Bogucice Sands (Neogene) aquifer (wells Nos. 11, 12, $22,23,24)$ reveal almost neutral, uniform $\mathrm{pH}$ values between 7.00 and 7.13 and are dominated by $\mathrm{HCO}_{3}^{-}, \mathrm{Ca}^{2+}$ and $\mathrm{Mg}^{2+}$ ions (Table 2). They show average TDIC content around $7.2 \mathrm{mmol} \mathrm{L}^{-1}$. Saturation indices with respect to calcite are close to zero indicating full development of carbonate mineralization. The partial pressure of $\mathrm{CO}_{2}$ controlling the observed carbonate chemistry calculated from the available chemical data varies between 0.018 and $0.032 \mathrm{~atm}$, in agreement with partial pressures of soil $\mathrm{CO}_{2}$ observed close to the study area (Dulinski et al., 2013). These waters contain elevated concentrations of sulfate ions, most probably originating from industrial pollution of the regional atmosphere during the second half of the 20th century.

Waters exploited by the Wola Batorska well field (wells Nos. 44-49) are dominated by $\mathrm{HCO}_{3}^{-}, \mathrm{Na}^{+}$and $\mathrm{Cl}^{-}$ions. The TDIC content is reduced by ca. $0.3 \mathrm{mmol} \mathrm{L}^{-1}$ when compared to waters from the recharge area. The $\mathrm{Ca}^{2+}$ and $\mathrm{Mg}^{2+}$ content is also reduced, while significantly higher $\mathrm{Na}^{+}$ concentrations are recorded (Table 2). These waters reveal elevated $\mathrm{pH}$ values (8.07-8.82) and are supersaturated with respect to both calcite and dolomite.

The observed patterns of geochemical evolution of groundwater in the studied part of the Bogucice Sands (Neogene) aquifer reflect its marine origin. Gradual freshening of the aquifer continuing since the Miocene involves ion exchange processes between the solution and the aquifer matrix. Waters dominated by $\mathrm{Ca}^{2+}$ and $\mathrm{Mg}^{2+}$ ions, while penetrating the aquifer, exchange those ions in favour of $\mathrm{Na}^{+}$ions which are released to the solution. Presence of this process is supported by Fig. 6 which shows the relationship between deficit of $\mathrm{Ca}^{2+}$ and $\mathrm{Mg}^{2+}$ ions with respect to the sum of $\mathrm{HCO}_{3}^{-}$and $\mathrm{SO}_{4}^{2-}$ ions and the excess of $\mathrm{Na}^{+}$and $\mathrm{K}^{+}$ions over the $\mathrm{Cl}^{-}$ions. The data points in Fig. 6 cluster along the

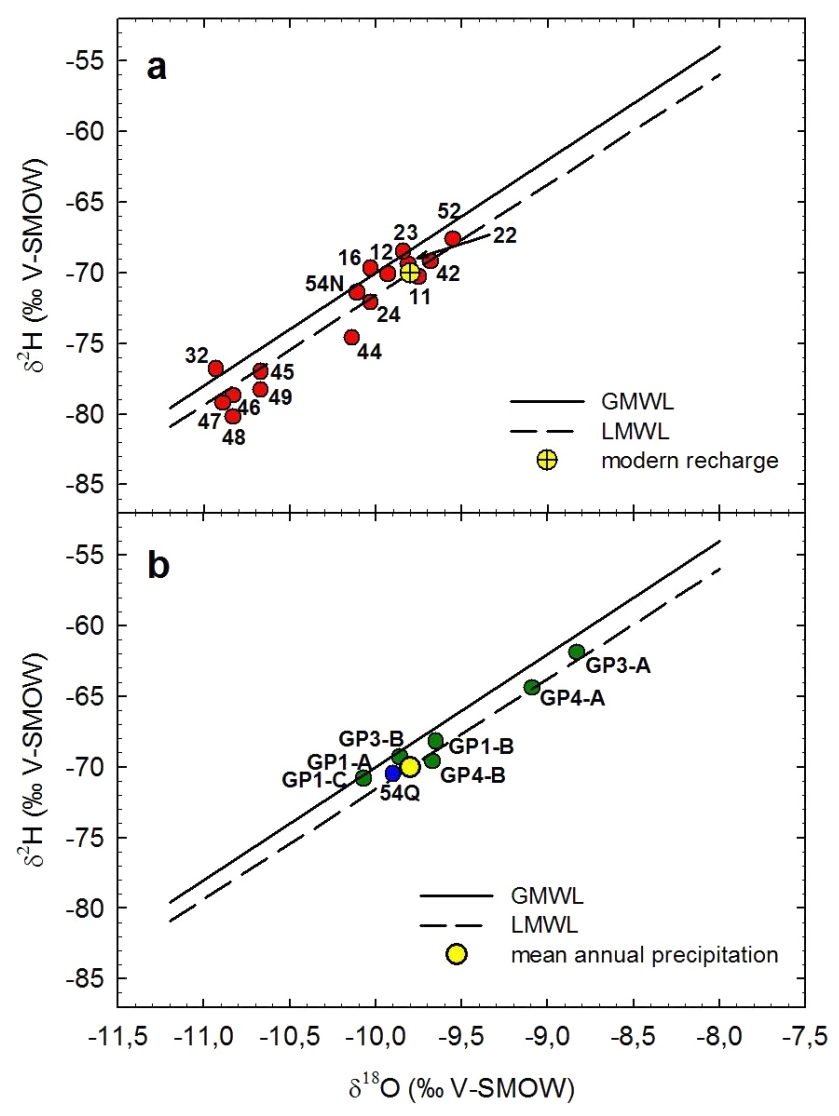

Figure 5. (a) $\delta^{2} \mathrm{H}-\delta^{18} \mathrm{O}$ relationship for groundwater samples representing the Neogene aquifer, collected in the study area. Mean isotopic composition of modern recharge of the aquifer is also shown. GMWL - global meteoric water line; LMWL - local meteoric water line (monthly precipitation at Krakow station, ca. $15 \mathrm{~km}$ northwest of the study area, collected during the period 1975-2013). (b) $\delta^{2} \mathrm{H}-$ $\delta^{18} \mathrm{O}$ relationship for groundwater samples representing shallow Quaternary aquifer underlying the Wielkie Błoto fen (see Figs. 1, 2 and Table 1).

charge equilibrium line confirming that chemical evolution of groundwater in the investigated part of Bogucice Sands aquifer is dominated by cation exchange processes. This conclusion is supported by Piper diagram shown in Fig. 7.

Inverse modelling of radiocarbon ages of groundwater in wells Nos. 16, 32, 42, 44, 46, 49, 52 and $54 \mathrm{~N}$ was performed using NETPATH code. First, the input solution representing the recharge area in the investigated part of Bogucice Sands (Neogene) aquifer was calculated. The calculations were based on chemical and isotope data available for wells Nos. 11, 12, 22, 23 and 24. Equal contribution of waters from those wells to the final solution was assumed. Carbon isotope parameters of the input solution were calculated as the mean values of respective parameters in individual waters contributing to the final solution, weighted by the size of carbonate reservoirs (TDIC). The calculated input carbon isotope values characterizing TDIC reservoir in the solution 
Table 3. Radiocarbon piston-flow ages of groundwater in the confined zone of the investigated part of the Neogene aquifer, calculated using NETPATH code.

\begin{tabular}{|c|c|c|c|c|c|c|}
\hline $\begin{array}{l}\text { Well } \\
\text { no. }\end{array}$ & $\begin{array}{r}\text { Measured } \delta^{13} \mathrm{C}_{\mathrm{TDIC}} \\
(\% \circ \mathrm{V}-\mathrm{PDB})\end{array}$ & $\begin{array}{r}\text { Computed } \delta^{13} \mathrm{C}_{\mathrm{TDIC}} \\
(\% \circ \mathrm{V}-\mathrm{PDB})\end{array}$ & $\begin{array}{r}\text { Measured }{ }^{14} \mathrm{C} \\
\text { content }^{\mathrm{a}}(\mathrm{pMC})\end{array}$ & $\begin{array}{r}{ }^{14} \mathrm{C} \text { age } \\
(\mathrm{ka})\end{array}$ & Constraints & Phases \\
\hline 16 & -13.3 & -12.9 & 32.2 & 5 & $\mathrm{C}, \mathrm{Ca}, \mathrm{Mg}$ & calcite, dolomite, \\
\hline 32 & -10.6 & -10.6 & $<0.7$ & $>36$ & $\mathrm{~K}, \mathrm{Na}, \mathrm{S}, \mathrm{Cl}$ & $\mathrm{CO}_{2}$ gas, halite, \\
\hline $42^{\mathrm{b}}$ & -12.2 & -12.2 & 48.5 & 2 & & sylvite, gypsum, \\
\hline 44 & -10.2 & -10.2 & 2.9 & 25 & & exchange, $\mathrm{CH}_{2} \mathrm{O}$, \\
\hline 46 & -10.5 & -10.7 & 0.8 & 34 & & $\mathrm{Mg} / \mathrm{Na}$ exchange \\
\hline 49 & -9.3 & -9.3 & 2.2 & 26 & & \\
\hline 52 & -12.8 & -12.9 & 36.9 & 6 & & \\
\hline $54 \mathrm{~N}^{\mathrm{c}}$ & -12.7 & -12.7 & 30.0 & 6 & & \\
\hline
\end{tabular}

${ }^{\text {a }}$ Carbon isotope and chemical analyses of water samples in collected in wells Nos. 44, 46 and 49 in June 2010 were used for NETPATH inverse calculations and determination of radiocarbon ages; ${ }^{\mathrm{b}}$ isotope exchange between solid carbonates and water solution to reconcile the computed $\delta^{13} \mathrm{C}$ of TDIC with observed value $\left(0.2-0.3 \mathrm{mmol} \mathrm{L}^{-1}\right.$ of exchanged carbon) was required only for well no. $42 ;^{\mathrm{c}}$ carbon isotope and chemical analyses of water sample collected in July 2014 were used for NETPATH inverse calculations and determination of radiocarbon ages.

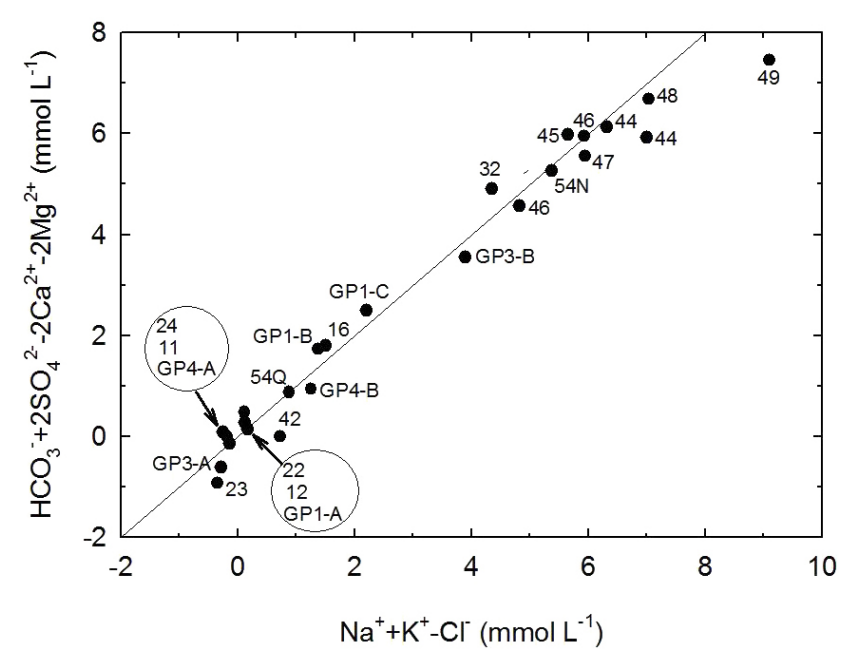

Figure 6. The relationship between deficit of $\mathrm{Ca}^{2+}$ and $\mathrm{Mg}^{2+}$ ions with respect to the sum of $\mathrm{HCO}_{3}^{-}$and $\mathrm{SO}_{4}^{2-}$ ions and the excess of $\mathrm{Na}^{+}$and $\mathrm{K}^{+}$ions over the $\mathrm{Cl}^{-}$ions in groundwater samples representing the part of the Neogene aquifer located in the study area and the shallow Quaternary aquifer in the area of Wielkie Błoto fen (see Table 2).

were $\delta^{13} \mathrm{C}=-13.4 \%,,{ }^{14} \mathrm{C}=64.1 \mathrm{pMC}$. The solution determined in this way was then used as the initial solution in inverse calculations using NETPATH code. Parameters used in the calculations (constraints and phases) and the resulting radiocarbon ages are summarized in Table 3 . The calculated radiocarbon ages vary from ca. $2 \mathrm{ka}$ for water in well no. 42 located close to the recharge area of the aquifer, up to the age in excess of ca. $36 \mathrm{ka}$ for well no. 32 located in most distant, northern part of the aquifer. Radiocarbon ages of three wells representing Wola Batorska well field (Nos. 44, 46 and 49) reveal radiocarbon ages between 25 and $34 \mathrm{ka}$, confirming the glacial origin of water in this well field, already apparent from the stable isotope data presented in Fig. 5. Well

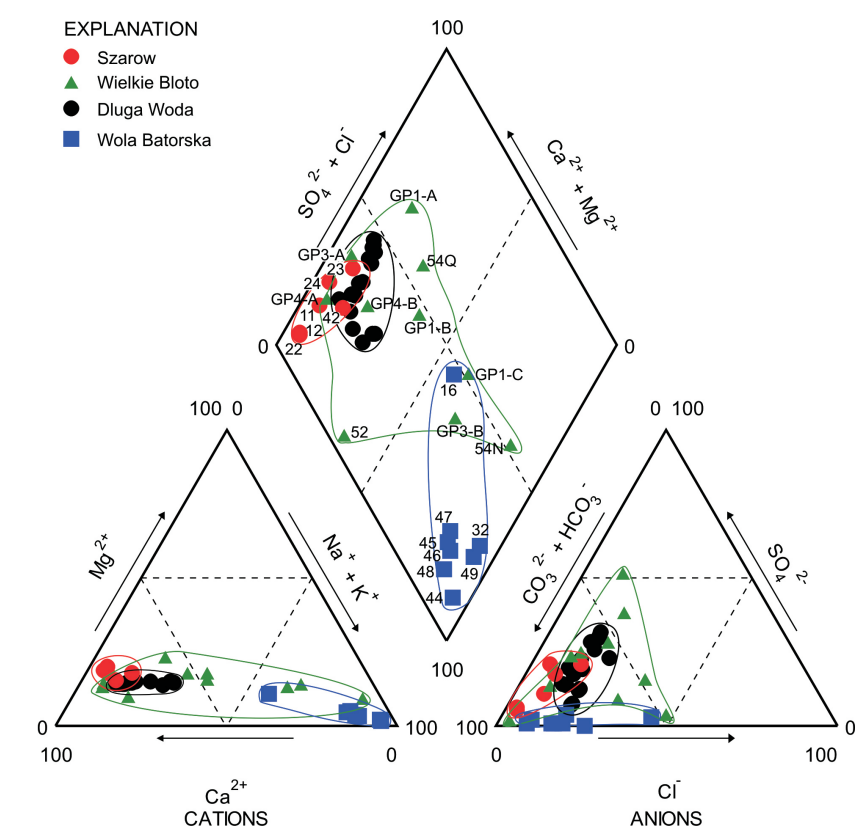

Figure 7. Piper diagram representing chemistry in water samples collected in the study area.

no. 54N, the "Anna Spring" (no. 52) and well no. 16 reveal mid-Holocene groundwater ages.

It is apparent from the above discussion that groundwater which eventually penetrates the confining layer and reaches the shallow Quaternary aquifer in the area of Wielkie Błoto fen should have distinct chemical and isotopic characteristics. In particular, it should be characterized by reduced $\mathrm{Ca}^{2+}$ and $\mathrm{Mg}^{2+}$ and elevated $\mathrm{Na}^{+}$content when compared to young groundwater present in the Quaternary cover. It should also have elevated $\mathrm{pH}$ values (around 8). This water does not contain tritium and is of Holocene age. The Holocene age of this water implies that its stable isotope signature will be 


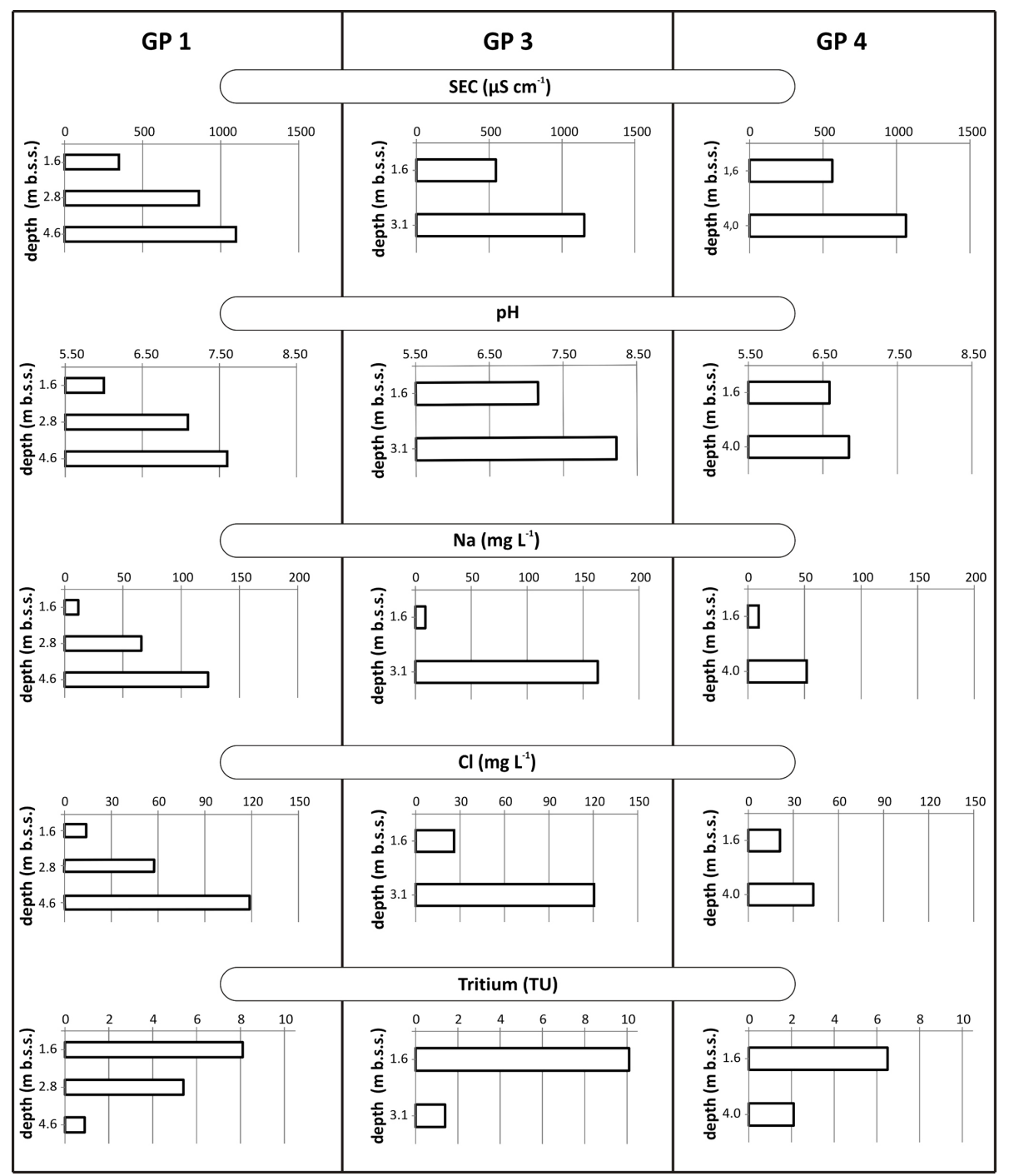

Figure 8. Depth stratification of $\mathrm{pH}$, conductivity, $\mathrm{Cl}, \mathrm{Na}$ and tritium content in the shallow Quaternary aquifer underlying the Wielkie Błoto fen and adjacent parts of the Niepolomice Forest. Water samples were collected with the aid of Geoprobe ${ }^{\circledR}$ device. Location of sampling sites (GP1, GP3, GP4) is shown in Fig. 2.

non-distinguishable from the mean isotopic composition of present-day precipitation in the area.

\subsection{Isotope and chemical stratification of shallow Quaternary aquifer in the area of Wielkie Błoto fen}

To investigate the isotopic and chemical stratification of groundwater in the shallow Quaternary aquifer underlying Wielkie Błoto fen, and to detect the eventual contribution coming from the deeper Neogene aquifer, a dedicated sampling campaign using Geoprobe ${ }^{\circledR}$ device was carried out in October 2011. Isotope and chemical data obtained for water samples collected during this campaign are summarized in Tables 1 and 2, respectively.

As seen in Fig. 5b and Table 1, stable isotope composition of Geoprobe ${ }^{\circledR}$ water samples varies significantly with depth and location. The deepest points cluster around the mean isotopic composition of local precipitation suggesting that the observed variability of $\delta^{2} \mathrm{H}$ and $\delta^{18} \mathrm{O}$ in the upper portions of the profiles stems from strong seasonality of $\delta^{2} \mathrm{H}$ and $\delta^{18} \mathrm{O}$ signal in local precipitation, surviving in the upper part of the Quaternary cover and converging towards the mean isotopic signature of the local precipitation at the bottom of this cover.

Vertical profiles of tritium content and selected chemical parameters are summarized in Fig. 8. A distinct reduction of tritium content with depth, accompanied by increase of $\mathrm{pH}$, conductivity and concentration of major ions $(\mathrm{Cl}$ and $\mathrm{Na}$ ) is apparent. The observed increase of $\mathrm{pH}$, conductivity and concentration of major ions $(\mathrm{Cl}$ and $\mathrm{Na}$ ) with depth in the shallow Quaternary aquifer, accompanied by reduction of tritium content, strongly suggest that upward seepage 
Table 4. Physico-chemical parameters of Dluga Woda stream monitored on a monthly basis during the period August 2011-August 2013 (n.m.: not measured).

\begin{tabular}{|c|c|c|c|c|c|c|c|c|}
\hline Date & $\begin{array}{l}\text { Flow } \\
\text { rate } \\
\left(\mathrm{L} \mathrm{s}^{-1}\right)\end{array}$ & $\begin{array}{l}\delta^{2} \mathrm{H} \\
(\% o)\end{array}$ & $\begin{array}{l}\delta^{18} \mathrm{O} \\
(\% o)\end{array}$ & $\begin{array}{l}\text { Tritium } \\
\text { content } \\
\text { (TU) }\end{array}$ & $\begin{array}{l}\text { SEC } \\
\left(\mu \mathrm{Ccm}^{-1}\right)\end{array}$ & $\mathrm{pH}$ & $\begin{array}{l}\mathrm{Cl} \\
\left(\mathrm{mg} \mathrm{L}^{-1}\right)\end{array}$ & $\begin{array}{l}\mathrm{Na} \\
\left(\mathrm{mg} \mathrm{L}^{-1}\right)\end{array}$ \\
\hline 16 Jul 2011 & 38.5 & n.m. & n.m. & n.m. & 562 & 7.75 & 25.1 & 17.2 \\
\hline 29 Aug 2011 & 10.1 & -62.7 & -8.70 & 5.9 & 559 & 7.86 & 33.2 & 31.9 \\
\hline 25 Sep 2011 & 1.0 & n.m. & n.m. & n.m. & 635 & 7.94 & 44.1 & 33.1 \\
\hline 29 Oct 2011 & 12.4 & -62.5 & -8.81 & 9.1 & 628 & 7.87 & 46.5 & 41.8 \\
\hline 29 Nov 2011 & 36.7 & -65.9 & -9.17 & 7.7 & 599 & 7.75 & 34.8 & 18.1 \\
\hline 30 Dec 2011 & 46.7 & -61.9 & -9.21 & 7.6 & 548 & 7.72 & 25.2 & 17.1 \\
\hline 28 Jan 2012 & 23.1 & -68.4 & -9.76 & 9.0 & 628 & 7.23 & 35.0 & 17.8 \\
\hline 29 Feb 2012 & 167 & -68.7 & -9.78 & 7.8 & 456 & 6.84 & 24.9 & 11.5 \\
\hline 31 Mar 2012 & 97.5 & -65.8 & -9.12 & 8.2 & 506 & 7.41 & 46.3 & 16.7 \\
\hline 30 Apr 2012 & 37.3 & -64.7 & -8.57 & 6.2 & 560 & 7.59 & 31.9 & 19.4 \\
\hline 30 May 2012 & 5.0 & -62.7 & -8.17 & 4.0 & 681 & 7.79 & 50.6 & 31.7 \\
\hline 22 Jun 2012 & 14.2 & -55.5 & -7.72 & 8.1 & 556 & 7.76 & 41.5 & 35.1 \\
\hline 30 Jul 2012 & 73.1 & -46.7 & -6.92 & 9.4 & 460 & 7.57 & 23.8 & 12.2 \\
\hline 31 Aug 2012 & 1.5 & -56.7 & -7.48 & 5.0 & 768 & 8.27 & 54.0 & 18.1 \\
\hline 28 Sep 2012 & 3.4 & -55.5 & -7.54 & 5.4 & 736 & 8.12 & 53.4 & 44.9 \\
\hline 30 Oct 2012 & 79.3 & -65.9 & -9.27 & 6.3 & 566 & 7.62 & 33.0 & 15.2 \\
\hline 29 Nov2012 & 42.2 & -63.8 & -9.01 & 5.4 & 573 & 7.75 & 30.1 & 20.5 \\
\hline 29 Dec 2012 & 89.4 & -76.2 & -9.39 & 7.0 & 567 & 7.48 & 33.6 & 17.2 \\
\hline 06 Mar 2013 & 128.3 & -70.2 & -9.97 & 5.7 & 501 & 7.44 & 31.2 & n.m. \\
\hline 20 Apr 2013 & 71.3 & -71.7 & -10.01 & 6.2 & 505 & 7.69 & 24.2 & 17.0 \\
\hline 08 Jun 2013 & 180.7 & -67.6 & -9.62 & 8.6 & 356 & 7.02 & 13.5 & 15.4 \\
\hline 06 Jul 2013 & 49 & -68.0 & -9.20 & 6.1 & 495 & 7.62 & 26.3 & 18.8 \\
\hline 09 Aug 2013 & 1.2 & -63.0 & -8.26 & 5.6 & 692 & 8.00 & 51.7 & 44.3 \\
\hline
\end{tabular}

of groundwater from deeper, confined Neogene aquifer indeed takes place in the area of Wielkie Błoto (Fig. 8). The chemical data of Geoprobe ${ }^{\circledR}$ water samples are also plotted in Figs. 6 and 7. They are consistent with the geochemical evolution of groundwater in the Neogene (Bogucice Sands) aquifer, discussed in the previous section.

\subsection{Water balance of the Dluga Woda catchment}

The catchment of Dluga Woda stream comprises Wielkie Błoto fen and adjacent parts of the Niepolomice Forest (see Fig. 2). Physico-chemical parameters of the stream water (flow rate, temperature, $\mathrm{pH}$, major ions, stable isotopes of water and tritium content) were monitored on a monthly basis over the 2-year period (August 2011-August 2013) with the main aim of detecting and quantifying the possible contribution of groundwater seeping from the deeper, confined aquifer to the shallow aquifer, in the total discharge of the Dluga Woda stream. The results are summarized in Table 4. Chemical data for the Dluga Woda stream are shown also on a Piper diagram (Fig. 7).

Figure 9 shows temporal variations of $\delta^{18} \mathrm{O}$ and tritium content in the Dluga Woda stream presented against the background of seasonal variability of those parameters in local monthly precipitation. It is apparent from Fig. 9a that the strong seasonality of $\delta^{18} \mathrm{O}$ in precipitation survives during transport through the watershed and is visible in the Dluga Woda $\delta^{18} \mathrm{O}$ record. However, the amplitude of seasonal changes of $\delta^{18} \mathrm{O}$ is significantly reduced: from approximately $5 \%$ oeen in precipitation to ca. $1.5 \%$ in the stream water. Maloszewski et al. (1983) have shown that the mean transit time of purely sinusoidal isotope input signal through a hydrological system characterized by an exponential distribution of transit times can be expressed by the following equation:

$\mathrm{MTT}=\frac{1}{2 \pi} \sqrt{\left(\frac{A_{\text {in }}}{A_{\text {out }}}\right)^{2}-1}$

where "MTT" is the mean transit time of water (in years), and $A_{\text {in }}$ and $A_{\text {out }}$ are the amplitudes of input and output isotope signals. The assumption about exponential distribution of transit times of water seems to be adequate to describe transport of precipitation input through a watershed. If the observed amplitudes of the input (precipitation) and output (stream) $\delta^{18} \mathrm{O}$ curves are inserted into Eq. (1) the resulting mean transit time of water through the catchment of Dluga Woda stream, relatively to the river section used for sampling water, is 3.2 months.

Figure $9 \mathrm{~b}$ shows the tritium content in local precipitation and in the Dluga Woda stream during the observation period. 


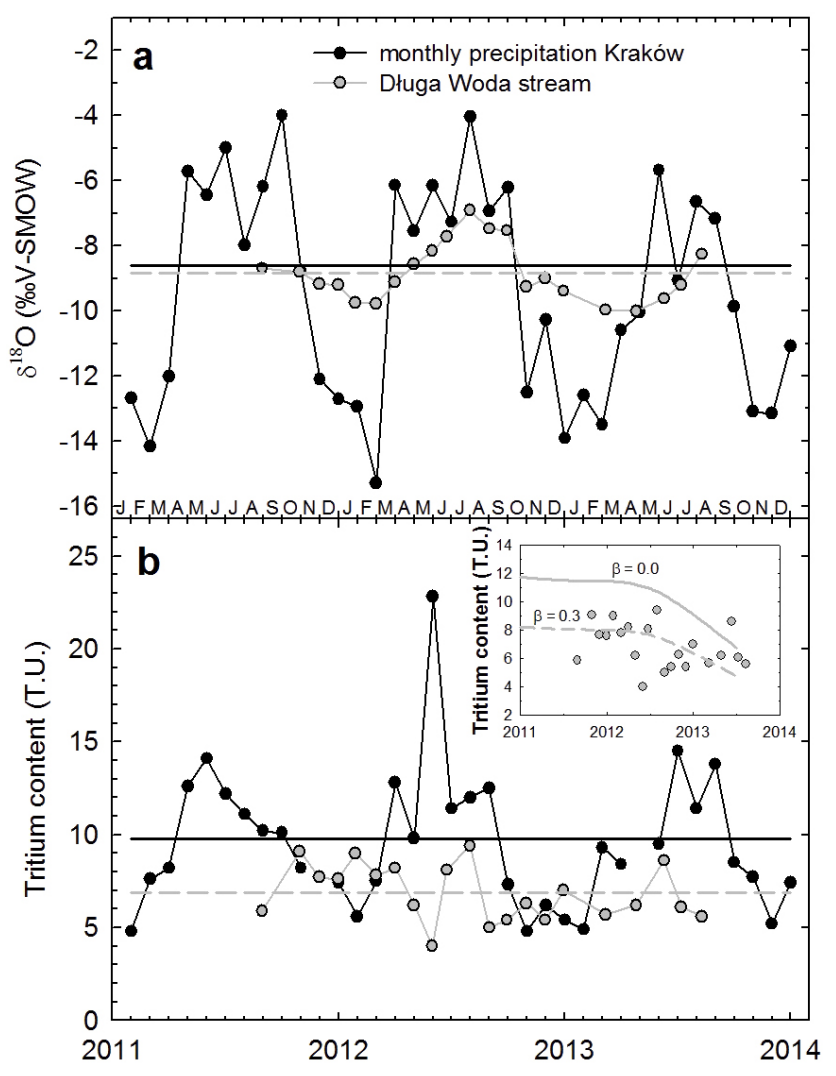

Figure 9. Seasonal variations of $\delta^{18} \mathrm{O}$ (a) and tritium content (b) in the Dluga Woda stream during the period 2011-2013. The inset in (b) shows the comparison of modelled and measured tritium concentrations in the Dluga Woda stream. $\beta$ is the fraction of tritiumfree component in the total flow of the stream (see text for details).

The weighted mean tritium concentration in precipitation $(9.8 \mathrm{TU})$ appears to be significantly higher than that of the Dluga Woda stream water (6.9 TU). Assuming that the total discharge of Dluga Woda is composed of a fast (MTT ca. 3.2 months) and a slow component devoid of tritium, the contribution of this old component can be easily assessed from first-order calculations based on tritium balance and is equal to approximately $30 \%$. A more appropriate approach based on lumped-parameter modelling (Maloszewski and Zuber, 1996) of tritium transport through the watershed of Dluga Woda stream confirms this rough assessment. The inset of Fig. $9 \mathrm{~b}$ shows the results of lumped-parameter modelling of tritium record in the Dluga Woda stream using the following prescribed parameters: (i) the mean transit time of water containing tritium in the catchment equal to 3.2 months, (ii) exponential distribution of transit times, and (iii) the contribution of tritium-free component in the Dluga Woda discharge equal to zero and $30 \%$, respectively $(\beta=0.0$ and 0.3 in the inset figure, where $\beta$ is the fraction of tritium-free component in the total flow of the stream). It is obvious that the assumption of $30 \%$ contribution of tritium-free component in the total discharge of Dluga Woda stream fits the experimen-

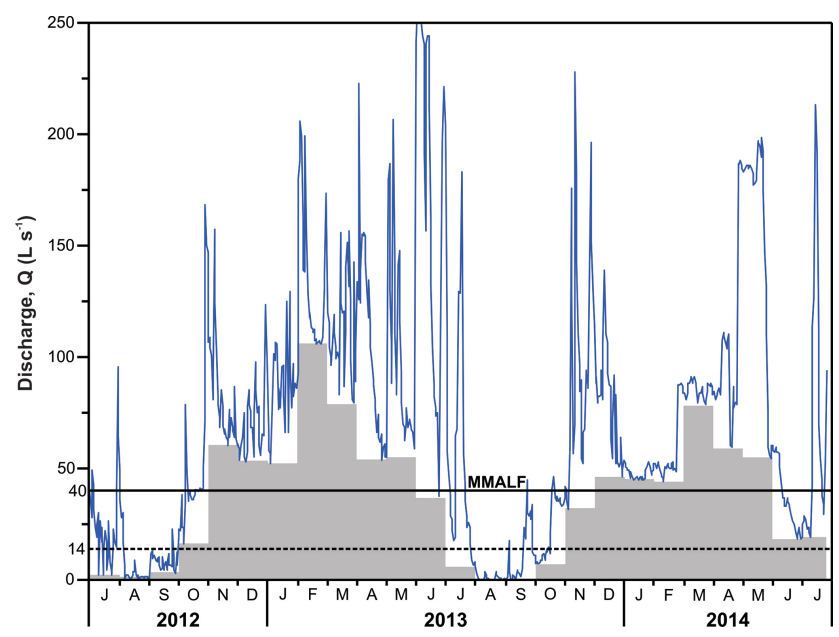

Figure 10. Hydrograph of Dluga Woda stream. Grey histogram reflects monthly low flows for the period July 2012-June 2014. The mean monthly annually low flow (MMALF) equal to $40 \mathrm{~L} \mathrm{~s}^{-1}$ corresponds to the baseflow of the stream. The characteristic discharge rate of $14 \mathrm{~L} \mathrm{~s}^{-1}$ (see Fig. 11) is marked by dashed line (see text).

tal data much better than the case neglecting this component. The contribution of tritium-free component also explains the difference between weighted mean $\delta^{18} \mathrm{O}$ in precipitation for the period January 2011-December $2013(-8.61 \%$ ) and the mean ${ }^{18} \mathrm{O}$ content of the Dluga Woda stream $(-8.84 \%$ ) seen in Fig. 9a. Mass-balance calculations based on $\delta^{18} \mathrm{O}$ data yield the contribution of the old component of the order of $20 \%$, assuming that its ${ }^{18} \mathrm{O}$ content is represented by the arithmetic mean of $\delta^{18} \mathrm{O}$ values available for "Anna Spring" and wells Nos. 16, 42 and 54Q, all characterized by Holocene ages of groundwater.

A hydrograph of the Dluga Woda stream constructed for the period July 2012-July 2014 is shown in Fig. 10. It reveals large variability of the flow rate. The measured values varied from ca. $1.5 \mathrm{~L} \mathrm{~s}^{-1}$ (31 August 2012) to $180 \mathrm{~L} \mathrm{~s}^{-1}$ (8 June 2013) (see Table 4), while the corresponding values derived from the rating curve were equal to $0.8 \mathrm{~L} \mathrm{~s}^{-1}$ (26 August 2012) and over $250 \mathrm{Ls}^{-1}$ (26 June 2013). Persisting low flows during August and September 2012 and 2013 resulted from lower than normal precipitation in the preceding months.

The hydrograph presented in Fig. 10 allows quantitative assessment of the Dluga Woda baseflow. It was derived as the mean monthly annual low flow (MMALF) according to Wundt (1953). "Low flow" defines the lowest flow during the given month. MMALF reflects the discharge of the aquifer and may represent the annual baseflow in the river catchment. The MMALF value for the period July 2012-July 2014 was equal to $40 \mathrm{~L} \mathrm{~s}^{-1}$. For the Dluga Woda catchment, with surface area of $8.2 \mathrm{~km}^{2}$, this flow rate corresponds to an annual baseflow equal to $154 \mathrm{~mm}$ (ca. $21 \%$ of annual precipitation rate). 

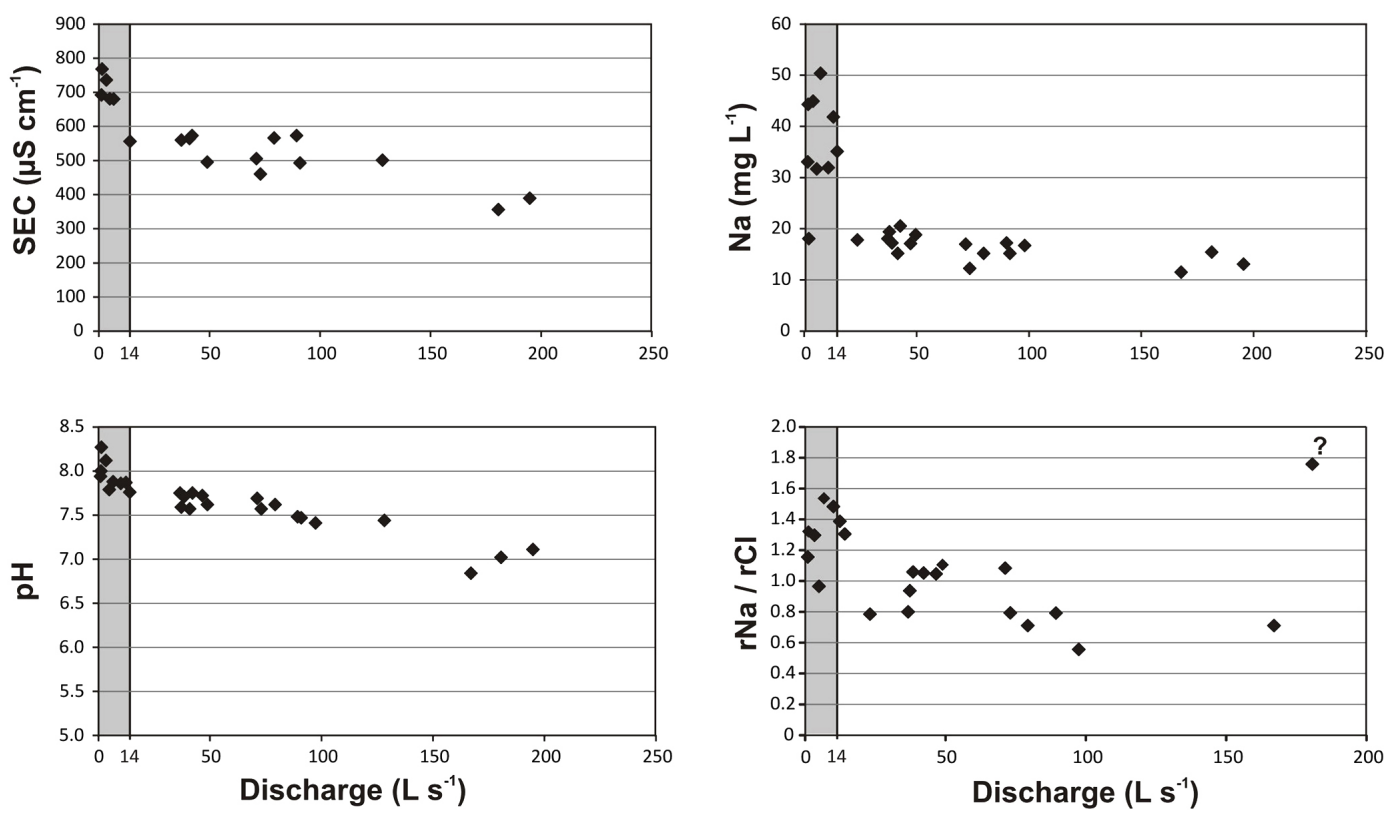

Figure 11. Electrical conductivity, $\mathrm{pH}, \mathrm{Na}$ content and $\mathrm{Na} / \mathrm{Cl}$ molar ratio in the Dluga Woda stream observed at monthly intervals during the period July 2011-June 2013, as a function of stream discharge rate measured at gauge station G (see Fig. 2).

Large fluctuations of Dluga Woda discharge rates are accompanied by substantial variability of the physico-chemical parameters of the stream water (see Table 4 and Fig. 11). The relationships between $\mathrm{SEC}, \mathrm{pH}, \mathrm{Na}$ content, $\mathrm{Na} / \mathrm{Cl}$ molar ratio and the discharge rate of Dluga Woda shown in Fig. 11 clearly indicate that for the flow rates lower than ca. $14 \mathrm{~L} \mathrm{~s}^{-1}$ the physico-chemical parameters of water attain distinct values $\left(\mathrm{SEC}>600 \mu \mathrm{S} \mathrm{cm}^{-1} ; \mathrm{pH}>7.8 ; \mathrm{Na}>30 \mathrm{mg} \mathrm{L}^{-1}, \mathrm{Na} / \mathrm{Cl}\right.$ ratio higher than 1.3) not observed for higher flow rates. In addition, these low flow rates are accompanied by low tritium contents in the stream water. High $\mathrm{pH}$ values and high $\mathrm{Na} / \mathrm{Cl}$ molar ratios in groundwater are typical for gradual freshening of sediments deposited in marine environment (Appelo and Postma, 2005). This strongly suggests that discharge of Dluga Woda stream at very low flow rates (ca. $<14 \mathrm{~L} \mathrm{~s}^{-1}$ ) carries significant contribution of waters seeping through clayey sediments separating water-bearing layers of the Neogene aquifer from the Quaternary shallow phreatic aquifer. Note that the flow rate of the order of $14 \mathrm{~L} \mathrm{~s}^{-1}$ constitutes approximately $30 \%$ of the MMALF value of $40 \mathrm{~L} \mathrm{~s}^{-1}$, remarkably close to the percentage contribution of the tritium-free component in the total discharge of Dluga Woda derived from tritium data.

\subsection{3-D flow and transport modelling of groundwater flow in the area of Wielkie Błoto fen}

The 3-D flow and transport model of the entire Bogucice Sands (Neogene) aquifer was calibrated with the aid of environmental tracer data (Zuber et al., 2005; Witczak et al., 2008). In the framework of the presented study this model was used to simulate the response of regional flow field to groundwater abstraction by the newly established Wola Batorska well field.

Figure 12 summarizes the measurements of the position of hydraulic head in well no. 32 located $1075 \mathrm{~m}$ north of the centre of Wola Batorska well field (see Fig. 2). The hydraulic head in this well changed radically after groundwater abstraction was initiated in July 2009. Initially slightly artesian, it stabilized at around $14 \mathrm{~m}$ below the surface after four years of operation of the new well field. Figure 12 also shows the changes of hydraulic head in well no. 32 simulated with the aid of a 3-D flow model forced by quarterly mean pumping rates of the entire well field. The agreement between modelled and observed evolution of the hydraulic head is satisfactory, particularly in the second part of the observation period.

The ratio of transmissivity to specific storage is a measure of the ability to transmit differences in hydraulic heads by groundwater systems (Alley et al., 2002, Sophocleous, 2012). The response of confined aquifers to changes in groundwater abstraction rates is relatively fast. The characteristic timescale of this response can be assessed using the approximate expression proposed by Alley et al. (2002):

$T^{*}=\frac{S_{\mathrm{S}} \cdot L_{\mathrm{C}}^{2}}{K}$,

where $T^{*}$ is the hydraulic response time for the basin (in days), $S_{\mathrm{S}}$ is specific storage $\left(\mathrm{m}^{-1}\right), L_{\mathrm{C}}$ is characteristic length $(\mathrm{m})$ of the basin and $K$ is hydraulic conductivity $\left(\mathrm{m} \mathrm{d}^{-1}\right)$. The response time of horizontal flow in the Bogucice Sands (Neogene) aquifer between the Wola Batorska 


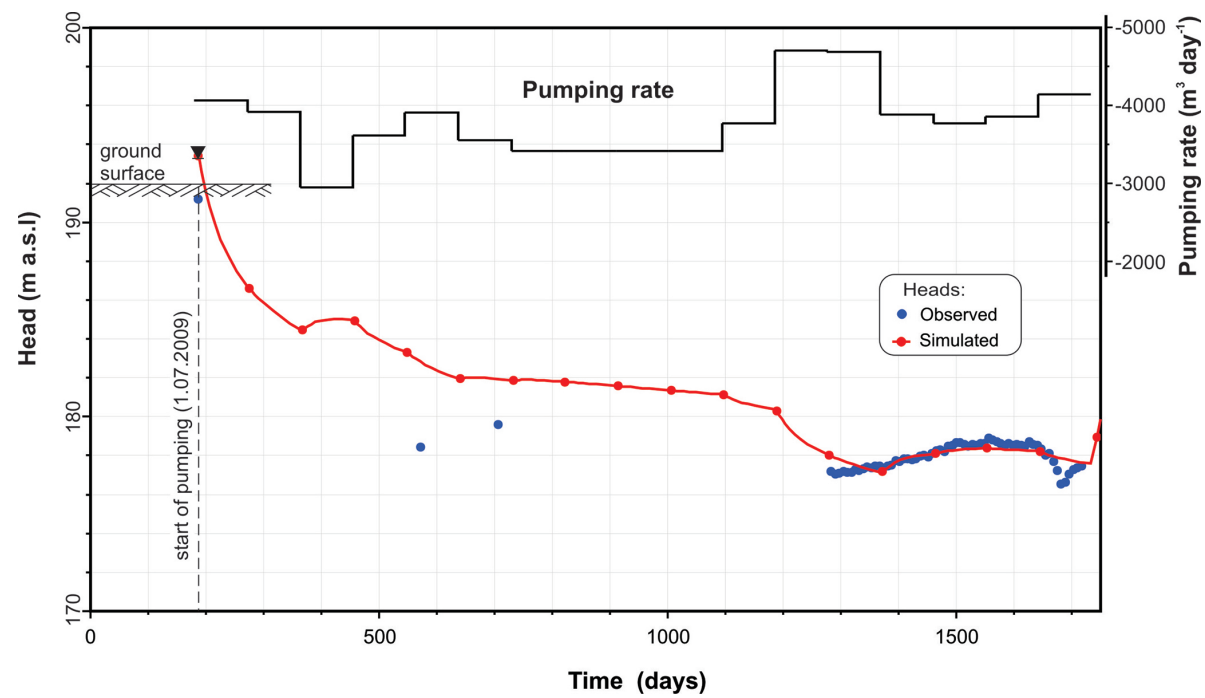

Figure 12. Changes of the hydraulic head in well no. 32 (see Fig. 2) after initialization of the operation of Wola Batorska well field in July 2009.

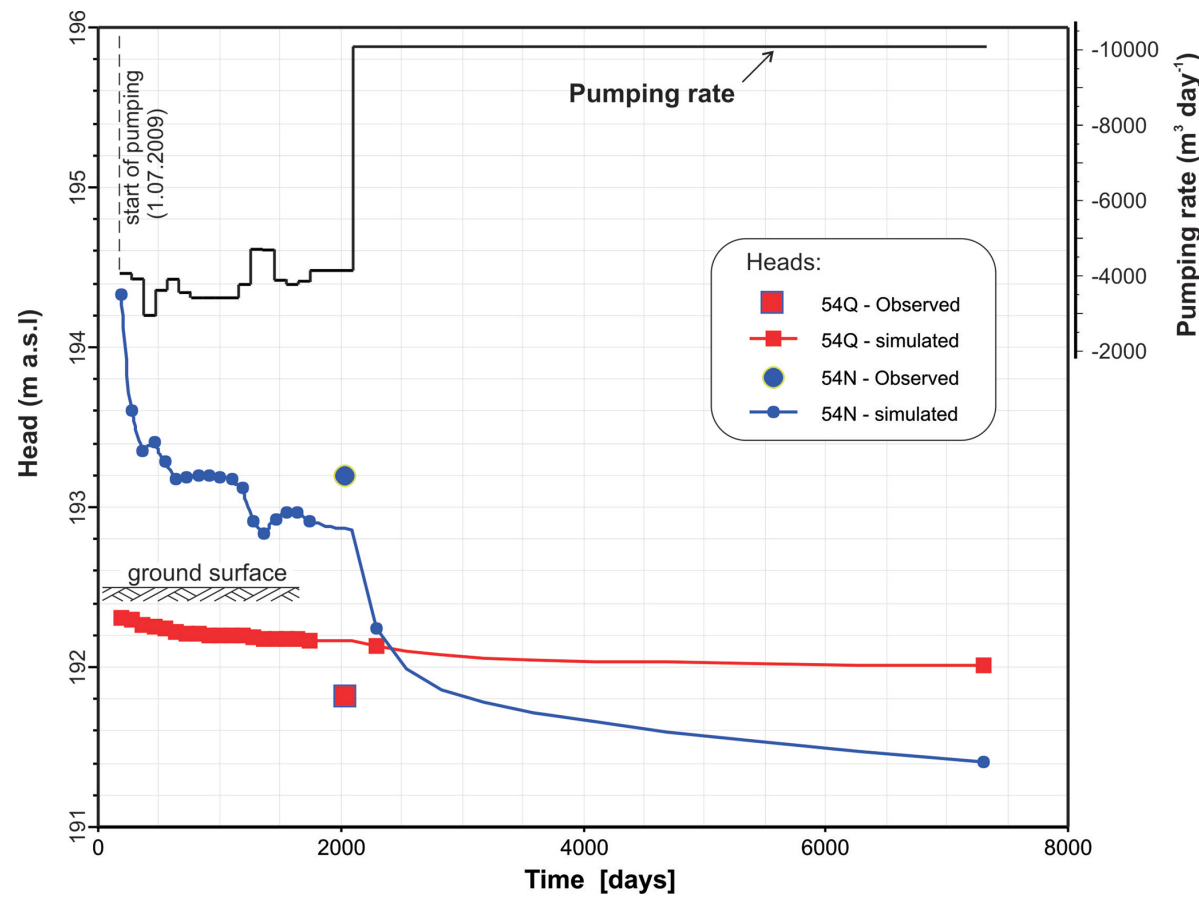

Figure 13. Changes of hydraulic heads in the shallow Quaternary and deeper Neogene aquifers in observation wells (54Q and 54N, respectively, see Fig. 2) simulated in the centre of the Wielkie Błoto fen. Pumping rate of Wola Batorska well field from the start in July 2009 till October 2014 was simulated as actual abstraction. The later part of the diagram shows future levels of groundwater abstraction with maximum permitted capacity $\left(10080 \mathrm{~m}^{3} \mathrm{day}^{-1}\right)$.

well field and the observation well (no. 32) was assessed using Eq. (2). With specific storage $S_{\mathrm{S}}=2.5 \times 10^{-5} \mathrm{~m}^{-1}$, derived from fitting of the measurement data shown in Fig. 12, the characteristic length $L_{\mathrm{C}}$ equal to $1075 \mathrm{~m}$ and the hydraulic conductivity $K$ set at $0.8 \mathrm{~m} \mathrm{~d}^{-1}$, the first-order assessment of the hydraulic response time of Bogucice Sands aquifer in the vicinity of Wola Batorska well field leads to a $T^{*}$ value equal to approximately 36 days.

The assessment of the impact of groundwater abstraction by the Wola Batorska well field to hydraulic head changes in well no. 32 allowed us to calibrate the initially steady-state flow model to transient conditions during the first 4 years 
of well field operation. Further, such a calibrated transient model allowed us to assess the expected lowering of the hydraulic heads in the Wielkie Błoto fen area and to quantify changes of the upward seepage of groundwater from the deeper Neogene confined aquifer to the shallow Quaternary aquifer and the Dluga Woda stream draining the Wielkie Błoto area. Figure 13 shows the expected changes of hydraulic head in Quaternary and Neogene aquifers with respect to the observation wells (54Q and 54N, respectively), simulated in the centre of the Wielkie Błoto fen. The simulation takes into account both the actual discharge of the Wola Batorska well field (2009-2014) and the prognosis of maximum allowed pumping rate $\left(10080 \mathrm{~m}^{3} \mathrm{~d}^{-1}\right)$ for the next 15 years, from the end of 2014 to the end of 2029.

Lowering of the simulated hydraulic head in both aquifers was generally confirmed by the observations in two monitoring wells (54Q and 54N ), starting from July 2014. The difference between simulated and observed heads is of the order of $30 \mathrm{~cm}$. The monitoring of hydraulic heads in both aquifers in the years to come will provide the basis for refinement of modelling results.

According to model output, the expected shortage of groundwater flow to the fen and the Dluga Woda stream depends strongly on adopted scenarios of expected pumping rates. Before initialization of groundwater exploitation by the Wola Batorska well field, the simulated upward seepage from the deeper confined aquifer to the shallow Quaternary aquifer was of the order of $441 \mathrm{~m}^{3} \mathrm{~d}^{-1}$. For the scenario with maximum permitted pumping capacity of the Wola Batorska well field $\left(10080 \mathrm{~m}^{3} \mathrm{~d}^{-1}\right)$ maintained from the end of 2014 to 2029 , this upward seepage will reverse to downward flow of approximately $465 \mathrm{~m}^{3} \mathrm{~d}^{-1}$ by the end of the simulation period. This means that the overall change will reach $906 \mathrm{~m}^{3} \mathrm{~d}^{-1}\left(10.5 \mathrm{~L} \mathrm{~s}^{-1}\right)$ in Dluga Woda outflow. It should be noted that simulations were run for mean yearly conditions. During low flow conditions occurring in the summer months (see Fig. 10) such drop of Dluga Woda discharge may lead to temporal disappearance of stream flow. By the end of the simulation period, the expected drop of water table in the centre of Wielkie Błoto fen (see Fig. 2) will be approximately $30 \mathrm{~cm}$ (from 192.31 to $192.00 \mathrm{~m}$ a.s.1.; see Fig. 13). It may be different for the wetland area. The climatic changes envisaged up to the end of 2029 were not considered in the simulation runs.

The impact of groundwater abstraction by the Wola Batorska well field, with the current mean pumping rate of ca. $3800 \mathrm{~m}^{3} \mathrm{~d}^{-1}$, is already seen in the flow field of the deeper Neogene aquifer. Although the hydraulic head has dropped by about $1.5 \mathrm{~m}$ (from 194.33 to $192.88 \mathrm{~m}$ a.s.l.) since the beginning of pumping in July 2009 up to July 2014 when monitoring wells Nos. 54Q and 54N were drilled, the artesian conditions in the deeper confined aquifer have been maintained (Fig. 13). This will, however, change in future when more intense abstraction of groundwater takes place. As shown in Fig. 13, the simulated hydraulic heads of both aquifers will be equal to approximately 310 days ( 0.85 years) after beginning of the exploitation of Wola Batorska well field with the maximum permitted capacity of $10080 \mathrm{~m}^{3} \mathrm{~d}^{-1}$. At the end of the simulation period (end of 2029) the hydraulic head in the deeper aquifer will be about $0.6 \mathrm{~m}$ lower than in the shallow aquifer.

\section{Conclusions}

Steadily growing anthropogenic pressure on groundwater resources, with respect to both their quality and quantity, creates a conflict situation between nature and man in their competition for clean and safe sources of water. It is often forgotten that groundwater-dependent ecosystems have important functions in all climatic zones as they contribute to biological and landscape diversity and provide important economic and social services. The presented study has demonstrated that isotope and geochemical tools combined with 3-D flow and transport modelling may help to answer important questions related to the functioning of groundwater-dependent ecosystems and their interaction with the associated aquifers.

In the context of the presented study environmental tracers appeared to be particularly useful in quantifying timescales of groundwater flow through various parts of the Bogucice Sands aquifer, including its Quaternary cover. Environmental tracer data (tritium, stable isotopes of water) and physicochemical parameters of groundwater and surface water in the study area provide strong collective evidence for upward seepage of groundwater from the deeper Neogene aquifer to the shallow Quaternary aquifer supporting the studied GDTE (Niepolomice forest and Wielkie Błoto fen).

Simulations of groundwater flow field with the aid of 3-D flow and the transport model developed for the studied aquifer and calibrated using environmental tracer data, strongly suggest that prolonged groundwater abstraction through the newly established cluster of water-supply wells at maximum permitted capacity $\left(\right.$ ca. $10000 \mathrm{~m}^{3} \mathrm{~d}^{-1}$ ) represents a significant risk to the studied GDTE. It may lead to reorganization of groundwater flow field in the study area and a significant drop in the water table, leading to degradation of this valuable groundwater-dependent ecosystem in the near future.

Acknowledgements. The study was supported by the GENESIS project funded by the European Commission 7FP (project contract 226536) and by statutory funds of the AGH University of Science and Technology (project nos. 11.11.220.01 and 11.11.140.026).

Edited by: C. Stumpp 


\section{References}

Alley, W. M., Healy, R. W., LaBaugh, J. W., and Reilly, T. E.: Flow and storage in groundwater systems, Science, 296, 1985-1990, 2002.

Appelo, C. A. J. and Postma, D.: Geochemistry, Groundwater and Pollution, 2nd Edn., A. A. Balkema Publishers, Amsterdam, the Netherlands, 649 pp., 2005.

Bertrand, G., Goldscheider, N., Gobat, J.-M. and Hunkeler, D.: Review: From multi-scale conceptualization to a classification system for inland groundwater-dependent ecosystems, Hydrogeol. J., 20, 5-25, 2012.

Bobachev, A.: Resistivity Sounding Interpretation - IPI2Win, Moscow State University, 2010.

Boulton, A. J.: Chances and challenges in the conservation of groundwaters and their dependent ecosystems, Aquat. Conserv., 15, 319-323, 2005.

Chełmicki, W., Ciszewski, S., and Żelazny, M.: Reconstructing groundwater level fluctuations in the 20th century in the forested catchment of Drwinka (Niepołomice Forest, S. Poland), in: Interdisciplinary Approaches in Small Catchment Hydrology: Monitoring and Research, edited by: Holko, L. and Miklanek, P., Proceedings of the 9th ERB Conference, Demanovska dolina, Slovakia, 25-28 September 2002, IHP Technical Documents in Hydrology, UNESCO, Paris, 67, 203-208, 2003.

Clark, I. D. and Fritz, P.: Environmental Isotopes in Hydrogeology, Lewis Publishers, New York, USA, 331 pp., 1997.

Coplen, T.: New guidelines for reporting stable hydrogen, carbon and oxygen isotope-ratio data, Geochim. Cosmochim. Ac., 60, 3359-3360, 1996.

Daniels, D. J.: Ground Penetrating Radar, 2nd Edn., The Institution of Electrical Engineers, London, UK, 726 pp., 2004.

Dresel, P. E., Clark, R., Cheng, X., Reid, M., Terry, A., Fawcett, J., and Cochrane, D.: Mapping Terrestrial Groundwater Dependent Ecosystems: Method Development and Example Output, Department of Primary Industries, Melbourne, Australia, 66 pp., 2010.

Dulinski, M., Rozanski, K., Kuc, T., Gorczyca, Z., Kania, J., and Kapusta, M.: Evolution of radiocarbon in a sandy aquifer across large temporal and spatial scales: case study from southern Poland, Radiocarbon, 55, 905-919, 2013.

EC: Directive 2000/60/EC of the European Parliament and of the Council establishing a framework for Community action in the field of water policy, OJ L 327, Office for Official Publications of the European Communities, Luxembourg, 2000.

EC: Common Implementation Strategy for the Water Framework Directive (2000/60/EC). The role of wetlands in the Water Framework Directive, Guidance document No. 12, Office for Official Publications of the European Communities, Luxembourg, 2003.

EC: Directive 2006/118/EC of the European Parliament and of the Council on the protection of groundwater against pollution and deterioration, OJ L 372, Office for Official Publications of the European Communities, Luxembourg, 2006.

EC: Common Implementation Strategy for the Water Framework Directive, Guidance on Risk Assessment and the Use of Conceptual Models for Groundwater, Guidance document No. 26, Office for Official Publications of the European Communities, Luxembourg, 2010.

EC: Common Implementation Strategy for the Water Framework Directive, Technical Report on Groundwater Dependent Ecosys- tems, Technical Report 6, Office for Official Publications of the European Communities, Luxembourg, 2011.

Florkowski, T., Grabczak, J., Kuc, T., and Rozanski, K.: Determination of radiocarbon in water by gas or liquid scintillation counting, Nukleonika, 20, 1053-1062, 1975.

Fontes, J. C. and Garnier, J. M.: Determination of the initial ${ }^{14} \mathrm{C}$ activity of total dissolved carbon: a review of existing models and a new approach, Water Resour. Res., 15, 399-413, 1979.

Forest Management Manual, The State Forests National Forest Holding, Warsaw, Poland, 655pp., 2012 (in Polish).

GENESIS: Deliverable 4.3: New indicators for assessing GDE vulnerability, available at:www.thegenesisproject.eu (last access: 15 December 2014), 2012.

Górka, J., Reczek, D., Gontarz, Ż, and Szklarz, K.: Annex to the Project Documenting Disposable Reserves of Groundwater and Delineating Protection Zones of Bogucice Sands Aquifer (GZWP 451), SEGI-AT Sp. z o.o., Warszawa, Poland, 2010 (in Polish).

Harbaugh, A. W., Banta, E. R., Hill, M. C., and McDonald, M. G.: MODFLOW-2000, the US Geological Survey Modular GroundWater Model - User Guide to Modularization Concepts and the Ground-Water Flow Process: US Geological Survey Open-File Report 00-92, Reston, Virginia, USA, 2000.

Hatton, T. and Evans, R.: Dependence of Ecosystems on Groundwater and its Significance to Australia, LWRRDC Occasional Paper No 12/98, Canberra, Australia, 1998.

Hill, M. C. and Tiedeman, C. R.: Effective Groundwater Model Calibration With Analysis of Data, Sensitivities, Predictions, and Uncertainty, John Wiley and Sons Inc., Hoboken, NJ, USA, 480pp., 2007.

Hose, G. C., Bailey, J., Stumpp, C., and Fryirs, K.: Groundwater depth and topography correlate with vegetation structure of an upland peat swamp, Budderoo Plateau, NSW, Australia, Ecohydrol., 7, 1392-1402, 2014.

Kinzelbach, W.: Groundwater Modeling: An Introduction with Sample Programs in BASIC. Elsevier Science Publishers B. V., Amsterdam, the Netherlands, 334 pp., 1986.

Kleczkowski, A. S. (Ed.): The Map of the Critical Protection Areas (CPA) of the Major Groundwater Basins (MGWB) in Poland, Institute of Hydrogeology and Engineering Geology, Academy of Mining and Metallurgy, Krakow, Poland, 44 pp., 1990.

Kløve, B., Ala-aho, P., Bertrand, G., Boukalova, Z., Ertürk, A., Goldscheider, N., Ilmonen, J., Karakaya, N., Kupfersberger, H., Kværner, J., Lundberg, A., Mileusnic' , M., Moszczynska, A., Muotka, T., Preda, E., Rossi, P., Siergieiev, D., Šimek, J., Wachniew, P., and Widerlund, A.: Groundwater dependent ecosystems: Part I - Hydroecology, threats and status of ecosystems, Environ. Sci. Pollut. R., 14, 770-781, 2011a.

Kløve, B., Ala-aho, P., Allan, A., Bertrand, G., Druzynska, E., Ertürk, A., Goldscheider, N., Henry, S., Karakaya, N., Karjalainen, T.P., Koundouri, P., Kværner, J., Lundberg, A. Muotka, T., Preda, E., Pulido Velázquez, M., and Schipper, P.: Groundwater dependent ecosystems: Part II - ecosystem services and management under risk of climate change and land-use management, Environ. Sci. Pollut. R., 14, 782-793, 2011 b.

Kløve, B., Ala-Aho, P., Bertrand, G., Gurdak, J. J., Kupfersberger, H., Kværner, J., Muotka T., Mykrä, H., Preda, E., Rossi, P., Bertacchi Uvo, C., Velasco, E., and Pulido-Velazquez, M.: Cli- 
mate change impacts on groundwater and dependent ecosystems, J. Hydrol., 518, 250-266, 2014.

Koefoed, O.: Geosounding Principles, 1: Resistivity Sounding Measurements, Elsevier, Amsterdam Oxford New York, 276 pp., 1979.

Lipka, K.: The Wielkie Błoto Peat Bog in the Niepołomice Forest Near Szarów, Przewodnik LX Zjazdu PTG, Kraków, Poland, 143-146, 1989 (in Polish).

Lipka, K., Zając, E., and Zarzycki, J.: Course of plant succession in the post-harvest and post-fire areas of the Wielkie Bloto fen in the Niepolomice Primeveal Forest, Acta Agrophysica 7, 433438, 2006.

Łajczak, A.: Geomorphological and hydrographic characterization of the "Royal Fern" nature reserve in the Niepolomice Forest, Ochrona Przyrody, 54, 81-90, 1997 (in Polish).

Małoszewski, P. and Zuber, A.: Lumped parameter models for the interpretation of environmental tracer data, in: Manual on Mathematical Models in Isotope Hydrogeology, IAEA-TECDOC-910, International Atomic Energy Agency, Vienna, Austria, 9-58, 1996.

Małoszewski, P., Rauert, W., Stichler, W., and Herrmann, A.: Application of flow models in an Alpine catchment area using tritium and deuterium data, J. Hydrol., 66, 319-330, 1983.

Mościcki, J.: Characterization of near-surface sediments based on DC resistivity soundings in the Starunia area, fore-Carpathian region, in: Ukraine: Polish and Ukrainian Geological Studies (2004-2005) at Starunia - the Area of Discoveries of Woolly Rhinoceroses, Polish Geological Institute and Society of Research on Environmental Changes "Geosphere", WarszawaKraków, Poland, 103-114, 2005.

Mook, W. G. and van der Plicht, J.: Reporting ${ }^{14} \mathrm{C}$ activities and concentrations, Radiocarbon, 41, 227-239, 1999.

Parkhurst, D. L. and Appelo, C. A. J.: User's Guide to PHREEQC (Version 2) - A Computer Program for Speciation, BatchReaction, One-Dimensional Transport, and Inverse Geochemical Calculations, Water-Resources Investigations Report no. 994259, USGS, Reston, Virginia, USA, 1999.

Pettit, N. E., Edwards, T., Boyd, T. C., and Froend, R. H.: Ecological Water Requirement (Interim) Framework Development, A conceptual framework for the maintenance of groundwater dependent ecosystems using state and transition modelling, Centre for Ecosystem Management, Report 2007-14, ECU Joondalup, Australia, 2007.

Plado, J., Sibul, I., Mustasaar, M., and Jõeleht, A.: Groundpenetrating radar study of the Rahivere peat bog, eastern Estonia, Est. J. Earth Sci., 60, 31-42, 2011.

Plummer, L. N., Prestemon, E. C., and Parkhurst, D. L.: An Interactive Code (NETPATH) for Modeling NET Geochemical Reactions Along a Flow PATH, Version 2.0, Water-Resources Investigations Report no. 94-4169, USGS, Reston, Virginia, USA, 1994.

Porebski, S. and Oszczypko, N.: Lithofacies and origin of the Bogucice Sands (Upper Badenian), Carpathian Foredeep, Proceedings of Polish Geological Institute, CLXVIII, 57-82, 1999 (in Polish).

Rozanski, K.: Deuterium and oxygen-18 in European groundwaters - link to atmospheric circulation in the past, Chem. Geol., 52, 349-363, 1985.
Salminen, R. (Ed.): Geochemical Atlas of Europe - Part 1: Background Information, Methodology and Maps, Geological Survey of Finland, Espoo, Finland, 2005.

Schaffers, A. P. and Sýkora, K. V.: Reliability of Ellenberg indicator values for moisture, nitrogen and soil reaction: a comparison with field measurements, J. Veg. Sci., 11, 225-244, 2000.

Schlumberger Water Services: Visual MODFLOW 2011.1 User's Manual; For Professional Applications in Three-Dimensional Groundwater Flow and Contaminant Transport Modeling, Schlumberger Water Services, Kitchener, Ontario, Canada, 2011.

Sinclair Knight Merz Pty Ltd.: Environmental Water Requirements of Groundwater Dependent Ecosystems, Environmental Flows Initiative Technical Report Number 2, Commonwealth of Australia, Canberra, 2001.

Slater, L. D. and Reeve, A.: Investigating peat stratigraphy and hydrology using integrated electrical geophysics, Geophysics, 67 365-378, 2002.

Sophocleous, M.: On understanding and predicting groundwater response time, Ground Water, 50, 528-540, 2012.

Stuiver, M. and Polach, H.: Discussion: reporting of 14C data. Radiocarbon, 22, 355-363, 1977.

Wachniew, P., Witczak, S., Postawa, A., Kania, J., Żurek, A., Różański, K., and Duliński, M.: Groundwater dependent ecosystems and man: conflicting groundwater uses, Geol. Q., 58, 595706, 2014.

Warner, B. G., Nobes, D. C., and Theimer, B. D.: An application of ground penetrating radar to peat stratigraphy of Ellice Swamp, southwestern Ontario, Can. J. Earth Sci., 27, 932-938, 1990.

Witczak, S., Zuber, A., Kmiecik, E., Kania, J., Szczepańska, J., and Różański, K.: Tracer based study of the Badenian Bogucice Sands aquifer, Poland, in: Natural Groundwater Quality, edited by: Edmunds, W. M. and Shand, P., Blackwell Publishing, Malden, MA, USA, 335-352, 2008.

Wundt, W.: Gewässerkunde, Springer-Verlag, Berlin Göttingen Heidelberg, 326 pp., 1953.

Zheng, C. and Wang, P. P.: MT3DMS, a Modular ThreeDimensional Multi-Species Transport Model for Simulations of Advection, Dispersion and Chemical Reactions of Contaminants in Groundwater Systems, Documentation and User's Guide, US Army Engineer Research and Development Center Contact Report SERDP-99-1, Vicksburg, MS, USA, 1999.

Zuber, A., Weise, S. M., Motyka, J., Osenbrück, K., and Rozanski, K.: Age and flow patter of groundwater in a Jurassic limestone aquifer and related Tertiary sands derived from combined isotope, noble gas and chemical data, J. Hydrol., 286, 87-112, 2004.

Zuber, A., Witczak, S., Rozanski, K., Sliwka, I., Opoka, M., Mochalski, P., Kuc, T., Karlikowska, J., Kania, J., JackowiczKorczynski, M., and Dulinski, M.: Groundwater dating with ${ }^{3} \mathrm{H}$ and $\mathrm{SF}_{6}$ in relation to mixing pattern, transport modelling and hydrochemistry, Hydrol. Process., 19, 2247-2275, 2005. 